(11) Nordic Council of Ministers

\title{
Mitigation \& Adaptation Synergies in the NDCs
}

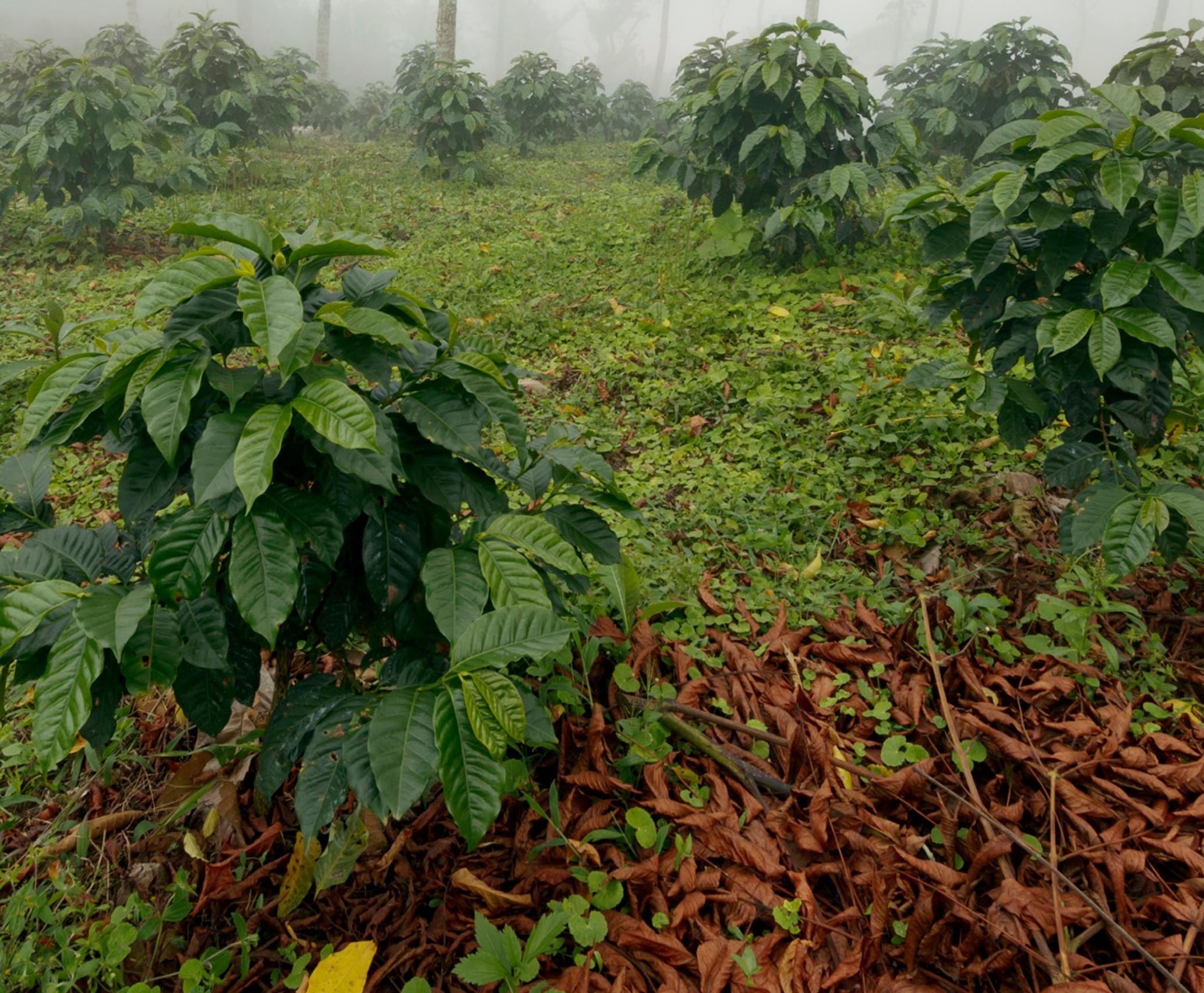





\section{Mitigation \& Adaptation Synergies in the NDCs}




\section{Mitigation \& Adaptation Synergies in the NDCs}

ISBN 978-92-893-4958-1 (PRINT)

ISBN 978-92-893-4959-8 (PDF)

ISBN 978-92-893-4960-4 (EPUB)

http://dx.doi.org/10.6027/TN2017-524

TemaNord 2017:524

ISSN $0908-6692$

Standard: PDF/UA-1

ISO 14289-1

(c) Nordic Council of Ministers 2017

Cover photo: unsplash.com

Printed in Denmark

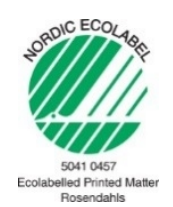

Although the Nordic Council of Ministers funded this publication, the contents do not necessarily reflect its views, policies or recommendations.

\section{Nordic co-operation}

Nordic co-operation is one of the world's most extensive forms of regional collaboration, involving Denmark, Finland, Iceland, Norway, Sweden, the Faroe Islands, Greenland, and Åland.

Nordic co-operation has firm traditions in politics, the economy, and culture. It plays an important role in European and international collaboration, and aims at creating a strong Nordic community in a strong Europe.

Nordic co-operation seeks to safeguard Nordic and regional interests and principles in the global community. Shared Nordic values help the region solidify its position as one of the world's most innovative and competitive. 


\section{Contents}

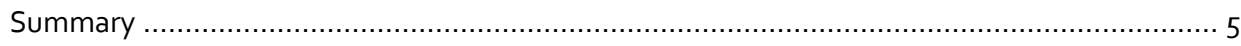

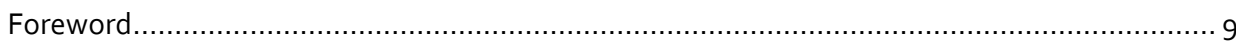

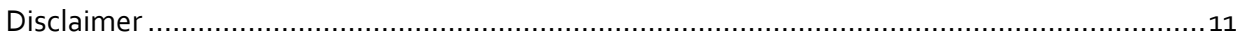

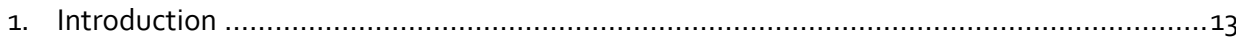

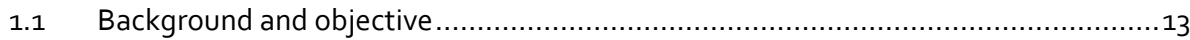

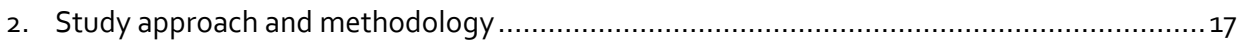

2.1 Defining mitigation and adaptation...........................................................

2.2 Synergies between mitigation and adaptation ................................................19

2.3 Synergies and trade-offs ........................................................................... 22

3. Review of recent studies of M\&A synergies in actions and policies in selected sectors ....... 25

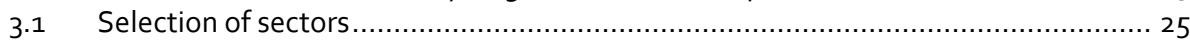

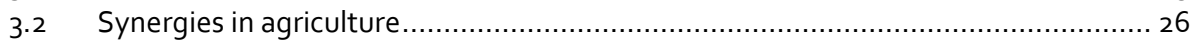

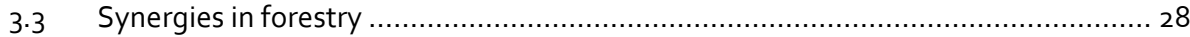

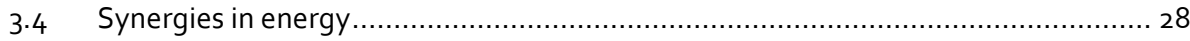

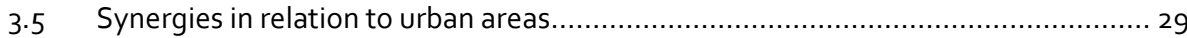

3.6 Cross cutting natural ecosystems approach ...................................................

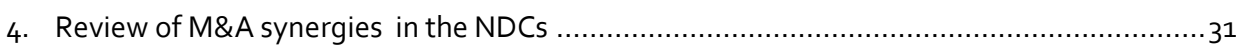

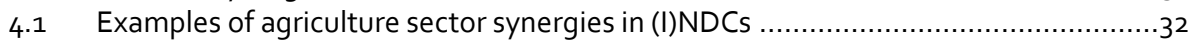

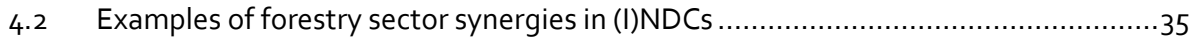

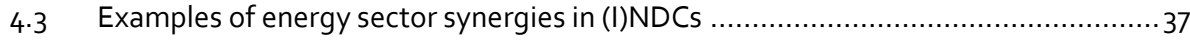

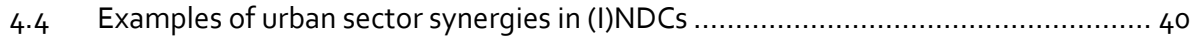

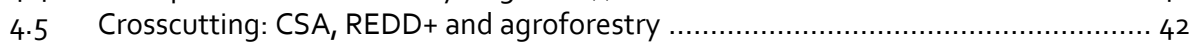

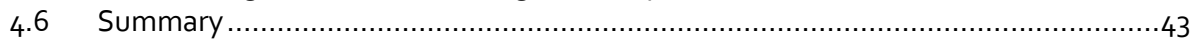

5. Identification of elements in the Paris Agreement with positive bearing towards $M \& A$

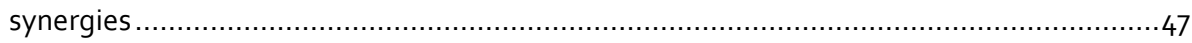

5.1 M\&A synergies in the purpose of the Agreement and the Decision ......................47

5.2 Types of M\&A found in the Agreement and its decision ................................... 48

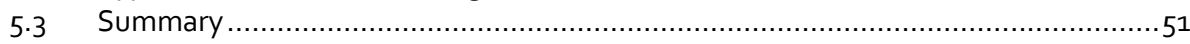

6. Examination of current climate funding criteria................................................. 53

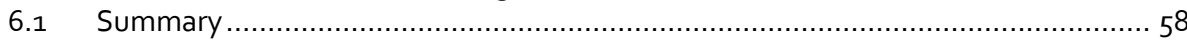

7. Exploring the feasibility for international climate finance supporting mitigation and

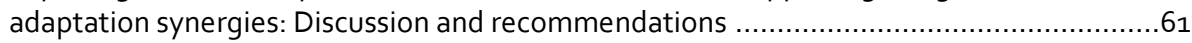

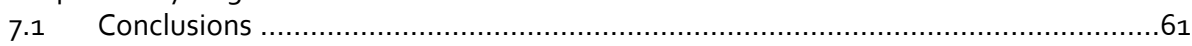

7.2 Recommendations: How to promote synergies in the future? ............................ 64

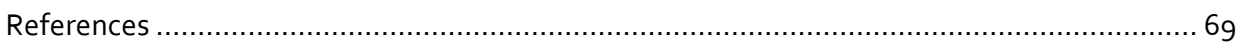

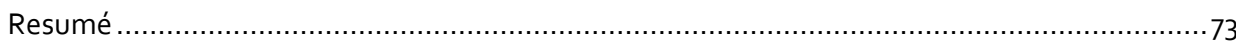

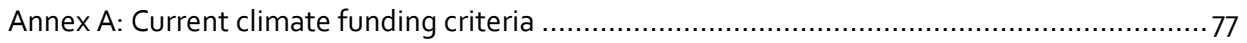





\section{Summary}

The implications of climate change are increasingly apparent, with clear impacts in terms of ecosystems, loss of biodiversity, patterns of catastrophic weather events, flooding, and impacts on agriculture. Action is required to address the impact of climate change while avoiding further problems. A range of solutions have been developed to react to changes in the climate, while others aim to prevent further damage. Recently, policy-makers have sought to address both needs by identifying synergies between adaptation and mitigation actions.

Synergies, as defined in the fourth IPCC Assessment Report can be understood as "interaction of adaptation and mitigation so that their combined effect is greater than the sum of their effects if implemented separately."

Conceptually, this synergy approach breaks down the traditional dichotomy of adaptation and mitigation as two separate domains and encourages integrated approaches at higher policy levels.

In practice, climate finance has been geared towards either mitigation or adaptation. Funding instruments do not explicitly promote mitigation and adaptation (M\&A) synergies. This is true in existing and emerging climate change agreements, notably in the Paris Agreement and several cooperation frameworks through which Nordic parties participate.

While the Paris Agreement offers the potential to generate synergies between mitigation and adaptation, the text does not compel the financing system to move in that direction. Nevertheless, latent potential exists for re-orienting the existing programme architecture towards the promotion of synergies between mitigation and adaptation through activities at the operational and programme level, using instruments such as refined eligibility requirements and updated reporting procedures that highlight synergies. Generating synergies will depend on the strategies of the stakeholders involved in negotiations and programme design.

This report is the outcome of a study on the "Mitigation \& Adaptation Synergies in the NDCs," prepared by COWI A/S for the Nordic Working Group for Global Climate Negotiations (NOAK) under the Nordic Council of Ministers. The objective for this study is to review mitigation and adaptation synergies in the submitted INDCs and explore and identify possible approaches to generate synergies, and linking these synergies to international climate financing opportunities.

The study focuses on forestry, agriculture, energy and urban development. Nordic countries have particular expertise in integrating and combining mitigation and adaptation actions within these thematic areas.

This report begins by developing a working model of the concept of synergies, providing a conceptual baseline for the analysis of recent studies on M\&A synergies. Shifting from theory to practice, the report contains an extensive review of developing 
country (I)NDCs to identify potential synergies and provides examples of synergies in the selected sectors.

This review is followed by an analysis of the elements in the Paris Agreement that could be applied to help support M\&A synergies. While the Paris agreement does not explicitly require $M \& A$ synergies, elements of the agreement provide opportunities for stakeholders to promote synergies through implementation. Using the same framework, the report reviews current climate funds and their funding criteria to assess how they could be used to promote M\&A synergies.

Ultimately, the review of practice found that there is room for improvement in the way that current climate funds address synergies between mitigation and adaptation. Funding models have shown little development towards the promotion of the M\&A synergies overall, with few exceptions. There has been some focus on the promotion of synergies at a higher strategic level. However, this has not necessarily materialised into specific eligibility or funding criteria for promotion of synergies, nor has it been integrated into the funds' application schemes, programmatic framework, monitoring and reporting requirements, or performance frameworks.

There is thus unharvested potential for strengthening the focus on M\&A synergies at all levels of the funds programme and project cycles. Despite the intention and willingness by climate funds to support NDCs in this regard, synergies will need to be operationalized in programme and specific project level design. As a principle, linking adaptation to mitigation and vice versa is an approach, not a target.

Given the scope for action in the current policy framework, Nordic stakeholders should push for specific actions in ongoing and future negotiations to drive further integration of M\&A synergies at the national and subnational level. As general principles, these include:

- Embed potential adaptation and mitigation benefits as a key criterion for action as well as in national strategy and action plan implementation.

- Identify policies that drive both adaptation and mitigation.

- Highlight synergies at multiple scales (local, regional, national, global) and across sectors (agriculture, forestry, energy, waste, industry, urban).

- Identify potential trade-offs and put in place measures to avoid or mitigate these.

- Develop institutional links between adaptation and mitigation, removing independent silos.

- Mainstream adaptation and mitigation considerations into broader development and economic policies.

- More specifically, for the Nordic parties involved in cooperation through the UNFCCC negotiations, there is an opportunity to push synergies from theory into practice.

- Strive to have synergies included in the common EU position on programme design.

- Require submitting parties to include information in future NDCs on how synergy between adaptation and mitigation actions has been promoted. 
- Sponsor and lead a specific Synergy Task Force, perhaps even allocating funding to synergy support for developing country parties.

- Require a dedicated synergies session under the Global Stocktake.

For the financing architecture, there is an opportunity for improvement in the way that current climate funds address synergies between mitigation and adaptation. Synergies have been identified and even articulated at a strategic level, but have not materialized into the specific fund investment criteria or at a project level.

Nordic stakeholders should implement the following actions at ongoing and future climate finance negotiations:

- Identify and integrate the relevant climate change aspects at all levels of the project and programme cycle will help generate relevant M\&A synergies.

- Develop a targeted project and programme preparation framework that ensures M\&A synergies, with monitoring and evaluation documentation that reports on synergy aspects within existing results-based management frameworks.

- Combine financing with an informational function to raise awareness and knowledge about potential synergies. Reporting requirements could stipulate a format for the presentation of analyses into synergies achieved, to facilitate more effective knowledge transfer.

- Issue specific guidance on how to address synergies between M\&A into national development frameworks, climate strategies, and action plans at various levels of government. This includes sector-specific action plans and specific programme and project development activities.

- Create tighter requirements for climate funds primarily addressing mitigation. For mitigation projects that may affect adaptation actions, a very wide degree is left to the discretion of the applicants/grantees whether to actually mention adaptation, vulnerability, and climate resilience aspects.

- Strengthen the information requirements on mitigation and adaptation synergy and trade-off aspects by explicitly requesting such information from applicants/grantees.

- Develop core indicators to support the promotion of synergy over time and over the course of the policy cycle. 



\section{Foreword}

The Paris Agreement adopted at COP 21 in Paris in December 2015 was the culmination of many years of climate negotiations. The Agreement entered into force in less than a year, thus demonstrating strong political commitment. Ahead of Paris, parties publicly outlined what post-2020 climate actions they intended to take under this new international agreement, known as their Intended Nationally Determined Contributions (I)NDCs. There is an increasing need to cope with and adapt to the impacts of climate change especially in developing countries.

Traditionally, climate finance has been geared towards either mitigation or adaptation. Few funding instruments have explicitly and systematically aimed to promote synergies of mitigation and adaptation even though the scientific research gives strong support to combine these two approaches in order to achieve larger climate benefits. This study is based on the (I)NDCs, and focuses on synergies between adaptation and mitigation in selected sectors and discusses features of potential financing design for adaptation and mitigation jointly.

COWI has carried out this study for NOAK, a working group under the Nordic Council of Ministers. The aim of NOAK is to contribute to an ambitious and effective implementation of the UNFCCC and its Paris Agreement, with a Nordic perspective. To this end, the group prepares studies and reports, conducts meetings, and organizes conferences supporting Nordic and international negotiators in the UN climate negotiations.

March 2017, Oslo

Peer Stiansen,

Chair of the Nordic Working Group for Global Climate Negotiations 



\section{Disclaimer}

The views and recommendations expressed in this report are the consultants' own and do not necessarily represent the views of the Nordic countries, The Nordic Council of Ministers, or the Nordic working group for global climate negotiations. 



\section{Introduction}

This report is the final output of the study on the "Mitigation \& Adaptation Synergies in the NDCs", prepared for the Nordic Working Group for Global Climate Negotiations (NOAK) under the Nordic Council of Ministers. COWI was commissioned to carry out the study.

The initial findings from the study were presented at the Nordic Pavilion on the Nordic Finance Day at COP22 in Marrakech on Thursday 17th November. Comments received from stakeholders, climate finance representatives, and the NOAK Steering Committee members have been integrated into the final version of the study.

\subsection{Background and objective}

The impacts of climate change are increasingly being felt around world. There is an urgent need to seek new climate funding sources and to make sure that current and future climate change funding is allocated and spent in the most efficient and effective manner.

The long-term goals of the Paris Agreement under the United Nations Framework Convention on Climate Change (UNFCCC) and the Sustainable Development Goals (SDGs) under the United Nations General Assembly (UNGA) as part of the 2030 Agenda for Sustainable Development require that climate action and climate finance deliver both on greenhouse gas emissions reductions and on adaptation and resilience in aligned and synergistic approaches.

A potential way for enhancing better synergies between adaptation and mitigation is to promote a more in-depth understanding of linkages and possible synergies between adaptation $(A)$ and mitigation $(M)$. For the NDCs, synergies will be a precondition for harvesting potential synergies and creating stronger alignment between adaptation and mitigation to deliver on climate targets as well as on wider sustainable development goals. Countries' future reporting under the Paris Agreement, as well as the sharing of experiences and best practices, will be an important building block in understanding how these synergies can be better reinforced in the future.

The objective for this study is to review mitigation and adaptation synergies in the submitted INDCs while identifying approaches that create synergies. The study also connects these synergies to opportunities for attracting international climate financing. The study focuses on forestry, agriculture, energy and urban development. Nordic countries have particular expertise in integrating and combining mitigation and adaptation actions in the thematic areas. These sectors are strong contributors to low-carbon growth.

The specific background for the study are the Intended Nationally Determined Contributions (INDCs) that Parties submitted to the UNFCCC in the run up to, during, and after COP21 in Paris in December 2015. Each INDC outlines the country's contributions 
in terms of greenhouse gas (GHG) mitigation targets and plans for addressing adaptation to climate change.

When a party has ratified the Paris Agreement, the INDC is no longer Intended and becomes a National Determined Contribution (NDC). ${ }^{1}$ This process is part of the Paris Agreement and NDCs, described in box 1.1 below. The Paris Agreement requires that all countries progressively increase the ambition of their climate actions communicated in their NDCs every five years, thus paving the way for regular revision and updating of national climate actions ahead of 2020.

\section{Status of the Paris Agreement and INDCs/NDCs}

Countries started submitting the INDCs more than six months before COP21 in Paris in December 2015. The French COP Presidency led the COP21 to the Paris Agreement. Less than one year later, on 5 th October 2016, the threshold for entry into force of the Paris Agreement was achieved and the Paris Agreement entered into force on 4 th November 2016.

As of 4 th January 2017, 121 countries representing over $98.9 \%$ of global emissions have ratified the Paris Agreement (UNFCCC, 2017; CAIT, 2017). The Agreement entered into force on 4th November 2016, a month after 55 countries representing $55 \%$ of global emissions had ratified it.

Out of the 194 Signatories 163 have submitted (I)NDCs, and out of these 121 have ratified (UNFCCC, 2017). Ratification of the Agreement means that countries will now move forward with implementation of climate actions identified in their Nationally Determined Contributions (NDCs) submitted to the UNFCCC.

The communication on INDCs for the post 2020 period was developed at COP19 (2013) and $C_{2 O P} 2$ (2014). The initial emphasis in the INDC decision was on mitigation and mitigation contributions to reduce global greenhouse gas emissions and limit the rise in global temperature to below 2 degrees compared to preindustrial levels. The inclusion of adaptation targets was agreed upon at COP2O. A total of 142 countries included mitigation and adaptation components in their INDC, providing detailed information (CAIT, 2017), which illustrates the significant momentum for pursuing relevant $M \& A$ synergies.

The purpose of exploring mitigation and adaptation synergies when addressing climate change is twofold. Firstly, there is a paradigm shift within climate change and environment policy towards mainstreaming and exploiting synergies between policy areas to develop policies that are as efficient and cost-effective as possible. ${ }^{2}$ Secondly, from the perspective of climate finance, exploring the M\&A synergies avoids trade-offs between mitigation and adaptation efforts.

In 2013, NOAK published a working paper "Scoping study on financing adaptation - mitigation synergies." 3 Now, in a Post-Paris Agreement era and the existence of the

\footnotetext{
${ }^{1}$ Hence forward, NDCs referred to in general will be identified as (I)NDCs, given that some of them are now ratified and thus NDC; others not and thus INDCs.

2 Examples EU mainstreaming and Danish Climate Policy Plan from 2013.

3 Scoping study on financing adaptation-mitigation synergy activities, Julia Illman, Mikko Halonen, Pasi Rinne, Saleemu

Huq and Svein Tveitdal NORDIC WORKING PAPERS, January 2013.
} 
(I)NDCs, the NOAK group sees a need for further exploring the synergies in the submitted (I)NDCs to exploit the potentially positive effects that climate finance could promote through M\&A synergies.

While this present study builds on the findings from the previous NOAK study, the present study contributes with new findings, including:

- Potential M\&A synergies expressed in the (I)NDCs.

- Enablers for M\&A synergies in the Paris Agreement under the UNFCCC.

- A comprehensive review of current funding criteria within major international climate change funds that have a suitable mandate for $M \& A$ synergies.

- Recommendations on the feasibility of international climate financing to focus and provide support to M\&A synergies as a way of enhancing ambitious climate actions to 2020 and beyond. 



\section{Study approach and methodology}

The study draws on an extensive review of climate change financing literature, a comprehensive analysis of submitted (I)NDCs, and an analysis of financial and policy frameworks and programmes that make up global climate change financing structure, notably the texts of the Paris Agreement. It also reviews the funding criteria of existing financing instruments that address climate change.

The study focuses on forestry, agriculture, energy and urban development. The Nordic countries have particular expertise in integrating and combining mitigation and adaptation actions in these thematic areas. These sectors are strong contributors to low-carbon growth, and the literature suggests that these sectors have close interlinkages with mitigation and adaptation actions. In the review of the (I)NDCs, we limit our focus to developing countries, since only developing countries receive climate funding. The study consists of several components.

- In the current chapter, we review concepts and definitions that are important for the analysis and M\&A synergies. This includes definitions of adaptation and mitigation. Examples of synergies between mitigation and adaptation are provided as part of this methodology chapter.

- Chapter three reviews recent studies on M\&A synergies within the four relevant sectors while investigating cross-cutting ecosystems approaches.

- Chapter four contains an extensive review of developing country (I)NDCs to identify potential synergies and provides examples of synergies occurring in the selected sectors. This comprehensive overview includes the types of synergies that are either explicitly stated in the (I)NDCs, or actions that have the potential of providing synergies even though the Party does not refer specifically to the synergistic effects of these actions.

- Chapter five provides an identification followed by an analysis of the elements in the Paris Agreement with potential M\&A synergies.

- Chapter six consists of an overview of the current climate funds and their funding criteria, outlining how these could either address or promote M\&A synergies.

- Chapter seven provides the final conclusions and recommendations of the study. 
Figure 1 below depicts the flow of the study.

Figure 1: The flow of the study

Chapter one:

Introduction and background of the study

Chapter two:

Study approach and methodology

\section{PHASE ONE: BACKGROUND ANALYSIS}

\section{Chapter three:}

Sector-wise review of recent studies

- Agriculture

- Forestry

- Energy

- Urban

- Cross cutting

\section{Chapter four:}

Extensive sector-wise review of developing countries (I)NDCs to identify potential synergies

\section{Chapter five:}

Identification of elements supporting M\&A synergies

in the Paris Agreement and the decision to its effect

\section{PHASE TWO: FEASIBILITY STUDY}

\section{Chapter six:}

Examination of the current funding criteria of international climate funds with suitable mandate for $M$ \& A synergies

Chapter seven:

Conclusions and recommendations

\subsection{Defining mitigation and adaptation}

The conceptual basis of the study is linked closely to the practical examples provided in subsequent chapters. The IPCC and the Fifth Assessment Report defines mitigation as a "human intervention to reduce the sources or enhance the sinks of greenhouse gases (GHGs)," while adaptation is defined as a "process of adjustment to actual or expected 
climate and its effects. In human systems, adaptation seeks to moderate or avoid harm or exploit beneficial opportunities" (IPCC, AR5 2014).

While mitigation is often well-understood, adaptation is conceptually more difficult to understand. Several differing definitions are found in the literature.

Following a definition of Thornton and Comberti (2013), adaptation consists of set of processes unfolding in response to a host of social and environmental forces operating over local, regional, national, international and planetary scales. Based on this, adaptive capacity is "the ability for human groups to successfully adjust to actual or expected environmental changes (especially climate change impacts) and their effects."

Adaption is often used in connection with the concept of resilience, as resilient systems often have larger adaptive capacity. In other words, a resilient energy system could be adaptable to changes in water availability and changes in demand and availability of biogenic resources.

However, the two concepts should not be confused, as resilience is "the capacity of social, economic, and environmental systems to cope with a hazardous event or trend or disturbance, responding or reorganizing in ways that maintain their essential function, identity, and structure, while also maintaining the capacity for adaptation, learning, and transformation" (IPCC, AR5 2014).

Essentially, being adaptive requires the capacity to be proactive and able to steer a development path in anticipation of resource constraints, while resilience is tied to a reactive position of being able to withstand or cope with shocks.

This study focuses on adaptation in terms of adjustment in natural or human systems in response to actual or expected climatic stimuli or their effects, which moderates harm or exploits beneficial opportunities.

\subsection{Synergies between mitigation and adaptation}

Feedbacks and inter-relationships between adaptation and mitigation, including synergies, have received some attention in recent literature, most importantly in the context of the work conducted under the auspices of the Intergovernmental Panel on Climate Change (IPCC) (c.f. Klein et al., 2007). Synergies, as defined in the fourth IPCC Assessment Report (Klein et al., 2007), can be understood as "interaction of adaptation and mitigation so that their combined effect is greater than the sum of their effects if implemented separately." ${ }^{\prime \prime}$

Among its conclusions on the work on inter-relationships between mitigation and adaptation, the IPCC stated that "significant co-benefits, synergies and trade-offs exist between adaptation and mitigation and among different adaptation responses; interactions occur both within and across regions and sectors" (IPCC, 2015).

In the context of synergies, it is important to note that M\&A synergies are greater than the sum of its individual parts. The combined effect is greater than the sum of the

4 This is also the definition used in the 2012 NOAK study on adaptation and mitigation synergies ("Scoping study on financing adaptation-mitigation synergy activities" by Ilman et al., 2012). 
activities if implemented separately (see Urvardy and Winkelman, 2014). In their work on inter-relationships between adaptation and mitigation, the IPCC captures this important type of synergy in their conceptual framework, which includes four different types of interaction:

- Adaptation actions that affect mitigation actions $(A \rightarrow M)$.

- Mitigation actions that affect adaptation actions $(M \rightarrow A)$.

- Decisions that include trade-offs or synergies between adaptation and mitigation $(((M, A))$.

- Processes that have consequences for both adaptation and mitigation $(A \cap M) .5$

As is identified in the previous NOAK study on synergies (Ilman et al., 2012), the concept of synergies is often taken to mean a range of different things, including links between, complementarity of, integration with, co-benefit, added value, and interaction between, adaptation and mitigation. They also note that often "synergies are examined in a broader sustainable development context and reference is often made to developing adaptive and mitigative or even response capacity, climate compatible development, reducing vulnerabilities, seeking co-benefits with development policy and enabling sustainable livelihoods."

Further reinforcing the concept, Leonard et al. (2016, who adapt their definition from Corning, 1998) define synergy as "combined or 'co-operative' effects; the effects produced by things that 'operate together'," meaning that effects produced by the whole are greater than the two parts operating alone (sometimes described using the "2+2=5"-metaphor).

These inter-relationships between mitigation and adaptation constitute the focus of this report. A third category emerges from the interaction. Namely, what can be seen as true synergies between adaptation and mitigation $\left(\int(M, A)\right)$.

In other words, an action needs to benefit both mitigation and adaptation to be labelled as a synergy. As such, the other three are understood as complementary actions, which can have co-benefits ( 1 and 2), or side-effects stemming from actions in other areas (4).

5 http://climatepolicyinfohub.eu/mitigation-co-benefits-and-interlinkages-adaptation 
The types of inter-relationships are shown schematically in Figure 2, below.

Figure 2: Inter-relationships between mitigation and adaptation

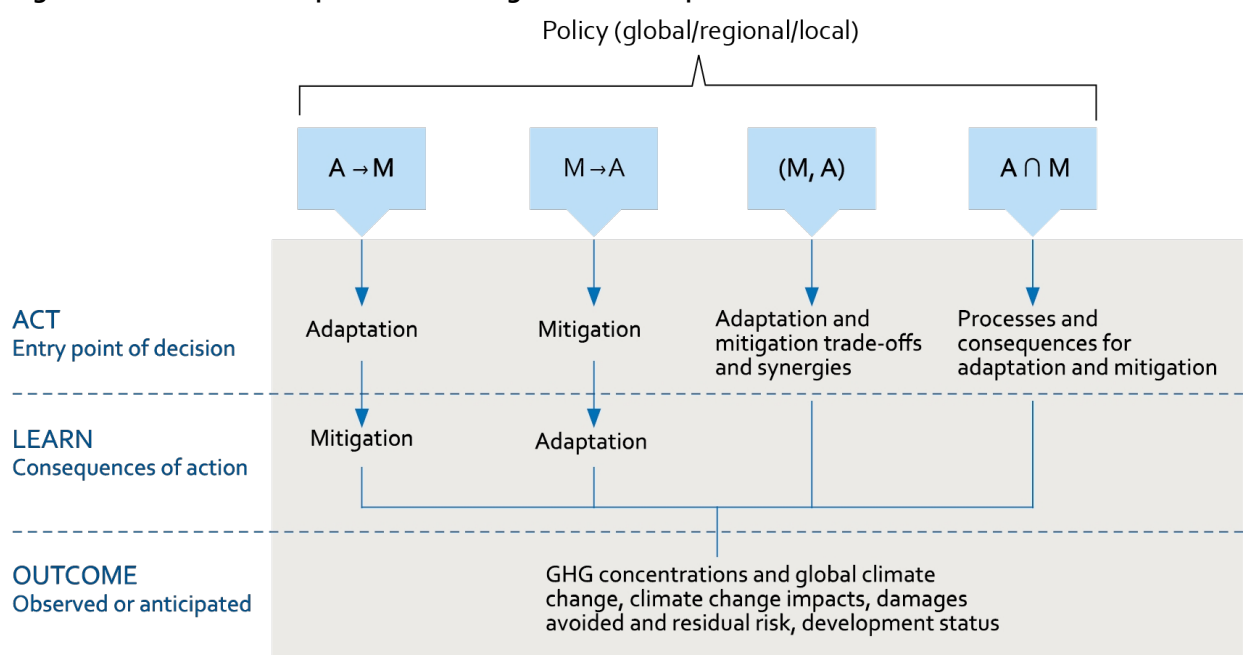

Source: Klein et al. (2007).

Synergies are not equally possible in all sectors. This is because inherent characteristics of the sector and various supportive elements (including technology, finance, social capital and know-how) that facilitate actions on mitigation and adaptation are not present nor needed to the same extent in the sectors.

As an example, some mitigation actions in the urban sector will require finance and technology, while others require know-how. Similarly, mitigation actions in the forestry sector to support afforestation is about social capital and know-how, whereas forest protection is generally dependent on a combination of finance and social capital.

In the following, typical actions and synergies will be discussed within four sectors: agriculture, forestry, energy, and urban areas. Actions are understood in the context of the definition applied by IPCC: "Adaptation and mitigation actions include technological, institutional and behavioural options, the introduction of economic and policy instruments to encourage the use of these options, and research and development to reduce uncertainty and to enhance the options' effectiveness and efficiency" (Klein et al., 2007).

In subsequent chapters, we identify examples of action and policy instruments where synergies exists between adaptation and mitigation $\left(\int(M, A)\right)$, while pointing out actions that are identified as synergies but in reality are co-benefits or side-effects. We also provide examples of actions where synergies could be developed but have not been identified as synergies. 


\subsection{Synergies and trade-offs}

Economic sectors compete over the same ecosystem resources, such as water, land, and other resources and services. Policy actions mirror this dynamic, with competing governance frameworks addressing the same targets using different approaches.

Figure 3 below demonstrates the nexus approach, which is an evolving research field that identifies ecosystem resources as shared resources. The figure shows the different drivers that create a demand for ecosystems resources, actions, and capacities that determine how the ecosystems are used. It also highlights results in terms of goals linked to climate change mitigation and adaptation.

Figure 3: The nexus approach illustrating drivers, actions, capacity and goals and results in relation to climate actions

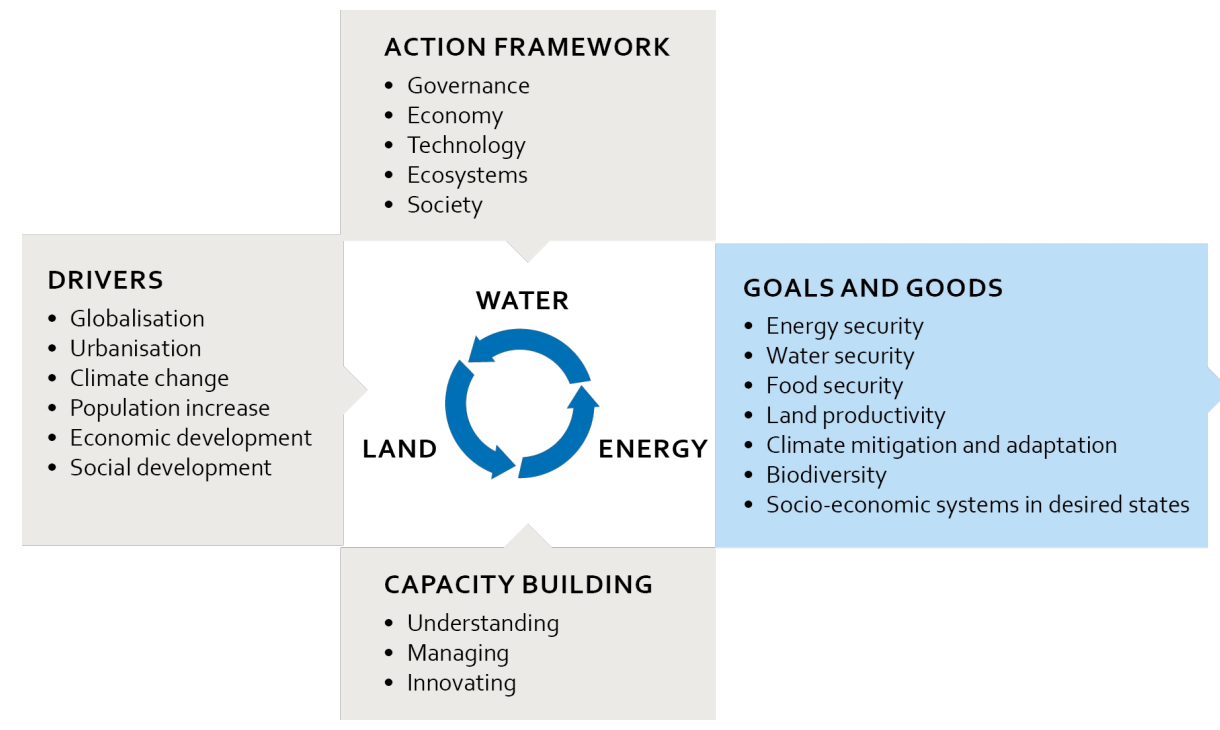

Source: Peter Stigson et al. (2014).

Potential positive effects of mitigation and adaptation actions that have effects beyond climate change are listed below. The positive impacts of synergies in terms of positive effects include goals and goods that are achieved as result of synergies, including:

- Resilience in ecological and technical systems.

- Labour and income.

- Water security.

- Food security.

- Land security.

In chapter three, we identify the synergies in the selected sectors on the basis of a literature review. In chapter four, potential synergies are identified in the (I)NDCs, including positive impacts achieved as a result of mitigation and adaptation actions. 
The approach also illustrates that decisions about mitigation and adaptation actions could compete for the same resources even though they result in synergies and co-benefits. To capture these conditions, we focus on the trade-offs. Trade-offs consist of negative effects that occur when actions compete over eco-systems resources. If negative effects occur in a business-as-usual scenario, dealing with those trade-offs could be understood as moving towards synergies.

Studies identifying synergies and trade-offs tend to focus on possibilities in landuse, biomass and ecological systems, rather than technical, economic and social systems. Synergies and trade-offs must be evaluated across spatial and chronological scales. Virtual impacts of imported goods (such as virtual water contents) must be included. Additionally, lock-in effects of investments in technological systems that will need to be resilient for changes in framework conditions over their lifetime must also be acknowledged. In the chapters below, the trade-offs will also be specified. 



\section{Review of recent studies of M\&A synergies in actions and policies in selected sectors}

This chapter provides an overview of potential synergies based on a review of the existing literature. Since the body of literature on climate change impacts, mitigation, and adaptation is very large, this study does not allow for a complete overview.

We have therefore focussed on the recent literature to capture the latest scientific findings on synergies between mitigation and adaptation. ${ }^{6}$ Evidence in the literature suggests that a small number of major sectors are responsible for a significant share of climate change, both in terms of causes and areas where implications have been identified. The review highlights synergies between mitigation and adaptation in agriculture, forestry, energy, and urban areas.

It also articulates a cross-sector framework that allows for broader synergies to be identified and captured. It is important to acknowledge the interlinkages that actions typically entail, which affects the scope of synergies and trade-offs in potential mitigation and adaptation actions. Analyses of synergies and trade-offs should, to the extent possible, acknowledge system complexity and avoid silo-based perspectives. Looking at linkages in smaller systems fails to identify the larger number of synergies and tradeoffs that de facto exist across sectors.

\subsection{Selection of sectors}

As background, the share of global emissions of the selected sectors is outlined below based on IPCC, 2014: ${ }^{7}$

- Emissions from agriculture and forestry, which include deforestation, emissions from soil and nutrient management, and livestock (all together labelled as AFOLU) is estimated to account for about a quarter of net anthropogenic emissions.

- Electricity and heat production accounts for about $25 \%$ of global emissions and considerably more when sectors such as industry (21\%), transportation (14\%) and buildings (6.4\%) are included. These energy-intensive sectors account for nearly all other emissions apart from AFOLU emissions.

\footnotetext{
${ }^{6}$ For a more detailed discussion, see e.g. UNEP DTU (2016); Illman et al., 2013; Duguma et al., 2014 and Rizvi et al., 2015). 7 IPCC (2014) Summary for Policymakers.
} 
- Urbanization is associated with migration from rural areas to urban areas and this trend generally means increases in income and higher consumption of energy. In 2006 , urban areas accounted for $67-76 \%$ of energy use and $71-76 \%$ of energyrelated $\mathrm{CO}_{2}$ emissions. By 2050, the urban population is expected to increase to 5.6-7.1 billion, or $64-69 \%$ of world population. Seen from a development perspective, cities in non-Annex I countries generally have higher levels of energy use compared to the national average, whereas cities in Annex I countries generally have lower energy use per capita than national averages.

However, it should be noted that sectors compete over the same ecosystem resources, in terms of water and land as well as other resources and services. This situation is exaggerated in urban areas, where ecosystems are used to supply local foods, local biofuels, water supply and reserves, recreational areas and biodiversity, as well as linked job and income opportunities.

\subsection{Synergies in agriculture}

Agriculture is an important sector in the context of mitigation and adaptation synergies. It has the potential to sequester emissions and is among the largest sources of anthropogenic emissions (approx. $10-12 \%$ of global non- $\mathrm{CO}_{2}$ GHG anthropogenic emissions in 2011). ${ }^{8}$

Many agricultural actions involve the use of land, water, resources, and energy. These have the potential to deliver both mitigation and adaptation, if designed correctly. Actions in the agricultural sector include soil conservation, plants and crops with higher drought and climate resilience, composting, mulching, improved irrigation and other more sustainable farming techniques, often grouped under the heading "climatesmart agriculture."

Mitigation possibilities target a number of components of agricultural production. This includes grazing land management and pasture improvement, management of organic soils, restoration of degraded lands, livestock and manure management, as well as the use of agriculture residues for bioenergy (Smith et al., 2008). Actions within these components involve sequestering carbon in soils, plants and biogenic products, managing nutrients and artificial and organic fertilisers, changing grazing practices and intensity, avoiding drainage, practicing low- or no tillage. Concerning livestock, actions include improving feeding practices, and breeding low emissions animal breeds (Smith et al., 2008; UNEP DTU, 2016; Duguma et al., 2014; Illman et al., 2013).

Several options are available for adapting crop and livestock production systems to climate change. Adaptation possibilities are diverse and targets different measures, such as improving soil nutrient content and water retention, possibilities for increased

\footnotetext{
${ }^{8}$ IPCC (2014) Agriculture, Forestry and Other Land Use (AFOLU). In: Climate Change (2014): Mitigation of Climate Change. Contribution of Working Group III to the Fifth Assessment Report of the Intergovernmental Panel on Climate Change, Cambridge University Press, Cambridge, United Kingdom and New York, NY, USA.
} 
soil resilience to drought, increased yields and increased nutrient contents in food and fodder, crop breeding for increased heat and/or water tolerance as well as food security (Illman et al., 2013; Harvey et al., 2013; Junghans et al., 2013; Lasco et al., 2014; Richards and Sander, 2014; UNEP DTU, 2016).

They also include advanced actions, such as using IT and Communication Technology (ICT) to provide weather information for farmers to help them manage the risks associated with temperature and rainfall variability, and implementing insurance schemes linked to weather indices (Thornton and Gerber, 2010). That being said, most adaptation options build on existing practices and sustainable agriculture, rather than being new technologies (Jarvis et al. 2011).

With regards to livestock, adaptation actions include breeding and cross-breeding programmes, or changing to more water and/or heat tolerant species. Indeed, mixed crop-livestock systems may be among the most promising means of adaptation to climate change. If well-designed, these systems potentially deliver mitigation benefits through integrated soil-crop-water management and improved water use efficiency (FAO, 2013).

Finally, with climate change leading to changes in presence and ranges of pests and diseases, as well as emergence of new pests, agricultural systems must adapt. Strategies for pest management include biological control, breeding for resistance to pests, intercropping and use of new cultivars, and changes in planting time (Legrève and Duveille 2010).

Both mitigation and adaptation measures can provide possibilities for economic and social benefits due to new and improved possibilities for farming. This is especially the case for smallholders that may have limited possibilities to adopt irrigation and artificial fertilising as means to adapt to climatic changes. Synergies in this field include water efficiency, which increases farming possibilities and resilience in arid and potentially future arid regions, often resulting in energy efficiency gains and thus mitigation potential (Hoff, 2011; Rodriguez et al., 2013). Improved farming conditions may also reduce the risk of soil degradation (Lasco et al., 2014; UNEP DTU, 2016). Moreover, it may maintain and improve biodiversity and important ecosystem services, such as pollination (FAO, 2011).

However, potential trade-offs include short-term yield loss while shifting towards crops, plants, and farming practices that increase carbon sequestration. There may also be competition over land and water resources, depending on local circumstances. Tradeoffs could occur in terms of reduced ecosystem services and biodiversity in the case of monocultures and intensive farming (Duguma et al., 2014; Illman et al., 2013; Rizvi et al., 2015; Junghans et al., 2013; UNEP DTU, 2016). Further, the potential of crop breeding and improved management practices is counteracted by situations where climate change involve multiple, interacting and sometimes reinforcing climatic stresses, such as drought, heat, loss of soil fertility, and reduced overall ecosystem services. 


\subsection{Synergies in forestry}

Synergies within forestry are often with the same as those in the agricultural sector. This includes carbon sequestration and prevention of soil degradation, as well as forestry as an economic activity and potentially important source of income.

Nevertheless, forestry holds specific potential synergies. Forests may, among other things, reduce evaporation and thus protect watersheds. This creates positive effects in terms of both mitigation, such as potential for hydropower, while offering adaptation such as the improved water resilience of species. Forests may also provide adaptation possibilities in terms of improving resilience of habitats due to improving coastal zone protection and heat resilience.

There are some limitations, however. The adaptive capacity of forests are not known, but intact forests are generally able to withstand some levels of climatic stress, though this depend on the specific biome. As with agriculture, forests might not be able to adapt in those cases where local climate changes rapidly to new precipitation and temperature regimes (Locatelli et al., 2008). As concerns forest plantations, the suite of adaptation actions available are similar to that of agriculture, as these are also intensively managed ecosystems and include changing management intensity and species composition (e.g. mix of hardwood and softwood species), age structure and harvest regime, and adjusting fire management regimes (Locatelli et al., 2008; Easterling et al., 2007).

Agroforestry systems are often highlighted as providing mitigation and adaptation synergies, as these systems can increase soil fertility, reduce soil erosion and provide other environmental and climate benefits, which can help farmers deal with increased temperatures and climate variability (Thorlakson and Neufeldt, 2012).

Trade-offs are similar to that of the agricultural sector, such as potential competition over resources and risks with monocultures. Also, as outlined in section 4.1.3, potential trade-offs exist in relation to biofuels and solid bioenergy. Some additional trade-offs relate to species that are effective in sequestering carbon but which may be less economically valuable or less climate resilient (Cavers and Cottrell, 2015).

It should also be noted that research has challenged the common understanding that mature forests sequester significantly lower rates of carbon than growing forests, although there are opposing views on this subject (Duguma et al., 2014; Illman et al., 2013; Klein et al., 2007; Swart and Raes, 2011; UNEP DTU, 2016).

\subsection{Synergies in energy}

Energy is a complex sector, with a range of potential synergies and trade-offs. These typically refer to increased use of renewable energy sources, as well as energy efficiency both in end-user, transmission, and conversion perspectives. 
As a key source of global $\mathrm{CO}_{2}$ emissions, mitigation perspectives mainly include the avoidance of fossil emissions of $\mathrm{CO}_{2}$ (Bruckner et al., 2014; Udvardy and Winkelman, 2014; Illman et al., 2013; Klein et al., 2007; Smith and Olesen, 2010; UNEP DTU, 2016).

However, it is important that a lifecycle perspective is adopted in valuing the marginal effects of using biogenic resources in reducing $\mathrm{CO}_{2}$ emission levels, for example through Indirect Land Use Change (ILUC) (Valin et al., 2015). This includes accounting for indirect effects, such as the emissions resulting from ILUC and potential leakage effects. To avoid trade-offs, possibilities to replace first generation biofuels with second or third generation should be evaluated.

Adaptation perspectives include a reduced sensitivity to oil price fluctuations and reduced dependence on fuel imports. Micro-generation and other means to improving access to electricity may reduce energy efficiency in households and reduce negative health impacts of, for example, using open fires for cooking as well as improved conditions for studying through better lighting (Duguma et al., 2014; Udvardy and Winkelman 2014; Illman et al., 2013; Smith and Olesen, 2010; Yadoo and Cruickshank, 2012).

The energy sector highlights potential trade-offs linked to the sectors of agriculture and forestry. An overall transition to bio-based economies may increase pressure on biogenic resources in both agriculture and forestry sectors. This transition can have consequences for land use decisions across micro, meso and macro scales, some of which may lead to increased emissions of GHGs. Inter-annual and seasonal variations in precipitation and projected changes in precipitation may question the long-term resilience of water intensive energy systems (Hoff, 2011; Rodriguez et al., 2013; Stigson et al., 2015).

\subsection{Synergies in relation to urban areas}

A characteristic of urban areas is that ecosystems are used to supply local foods, local biofuels, water supply and reserves, recreational areas and biodiversity, as well as linked job and income opportunities. A key to evaluating the synergies and trade-offs in urban areas lies in understanding the effects of urbanisation, which includes increased stress on local ecosystem services and resources. ${ }^{9}$

Several measures may be adopted to provide benefits of reduced energy use and increased climate resilience. Possible actions include establishing green structures, such as parks, grass grids instead of hard surfaces, and green building surfaces and roofs. These green structures have been found to improve storm water handling, lower the heat island effect of cities, improve local air quality, and support pollinating species.

Given the intensification of resource and energy use in urban areas, opportunities for adaptation include decreasing the stress on systems that supply needed goods and services. Most of these systems are affected by climate change, such as ecosystems, systems for heating and cooling, transportation systems, sewage and water management. Increasing mitigation and adaptation will contribute to the climate resilience of

9 However, acknowledging that urbanisation may also provide benefits in terms of job opportunities, shorter travel time, higher income, etc. 
cities (Udvardy and Winkelman, 2014; Levine et al., 2007; Lucon et al., 2014; Seto et al., 2014; Swart and Raes; 2011). Seeing that actions for mitigation in urban areas typically relate to energy and water efficiency as well as increasing green areas, trade-offs are less obvious.

\subsection{Cross cutting natural ecosystems approach}

Analyses of synergies and trade-offs should, to the extent possible, acknowledge system complexity and avoid silo-based approaches. Limiting analysis to smaller systems fails to identify the larger number of synergies and trade-offs that de facto exist across sectors. A smart climate solution in the field of mitigation and adaptation needs to be smart in the perspective of interlinked energy, water, and land-use systems.

Indeed, broader systems provide larger opportunities to identify synergies. This includes the water intensity of biofuels and hydropower, the energy intensity of desalinisation and transporting water, the competition over land areas for the provision of local biofuels, local food production, recreational areas, urbanisation, infrastructure and other needs. 


\section{Review of M\&A synergies in the NDCs}

This chapter offers a comprehensive screening and review of the (I)NDCs to identify specific examples of synergies, co-benefits and other inter-relationships.

We performed an initial screening of all developing country (I)NDCs based on key words related to inter-relationships and synergies such as "synergy," or "co-benefit," and other relevant terms. The review identified synergies and parallel inter-relationships within various sectors of the (I)NDCs. This was complemented by a cross-reading of actions that contain elements of both adaptation and mitigation. The result of the screening is shown the table below.

Table 1: Review of (I)NDC inter-relationships

\begin{tabular}{|c|c|c|}
\hline & $\begin{array}{l}\text { Explicit consideration of M\&A synergies } \\
\text { or co-benefits }\end{array}$ & Does not consider M\&A synergies \\
\hline Africa & $\begin{array}{l}\text { Burkina Faso, Cameroon, Cape Verde, Cen- } \\
\text { tral African Republic, Côte d'Ivoire, Ethio- } \\
\text { pia, Ghana, Kenya, Madagascar, Malawi, } \\
\text { Mali, Mauritius, Namibia, Niger, Nigeria, } \\
\text { Rwanda, Seychelles, Swaziland, Togo, } \\
\text { Uganda, Zambia }\end{array}$ & $\begin{array}{l}\text { Angola, Benin, Botswana, Burundi, Chad, Comoros, } \\
\text { Congo, Democratic Republic of the Congo, Djibouti, } \\
\text { Equatorial Guinea, Eritrea, Gabon, Gambia, Guinea, } \\
\text { Guinea Bissau, Lesotho, Liberia, Mauritania, Mozam- } \\
\text { bique, Sao Tome and Principe, Senegal, Sierra Leone, } \\
\text { South Africa, Somalia, South Sudan, Sudan, United } \\
\text { Republic of Tanzania, Zimbabwe }\end{array}$ \\
\hline $\begin{array}{l}\text { East Asia and } \\
\text { Pacific }\end{array}$ & $\begin{array}{l}\text { Cambodia, Lao, Marshall Islands, Myanmar, } \\
\text { Philippines, Tonga }\end{array}$ & $\begin{array}{l}\text { Brunei Darussalam, China, Cook Islands, Fiji, Indone- } \\
\text { sia, Kiribati, Malaysia, Micronesia, Nauru, Palau, Sa- } \\
\text { moa, Solomon Islands, Sri Lanka, Thailand, Tuvalu, } \\
\text { Vanuatu, Vietnam }\end{array}$ \\
\hline $\begin{array}{l}\text { Latin America } \\
\text { and Caribbean }\end{array}$ & $\begin{array}{l}\text { Bolivia, Costa Rica, Ecuador, Mexico, Para- } \\
\text { guay }\end{array}$ & $\begin{array}{l}\text { Antigua and Barbuda, Argentina, Bahamas, Barba- } \\
\text { dos, Belize, Brazil, Chile, Colombia, Cuba, Dominica, } \\
\text { Dominican Republic, El Salvador, Grenada, Guate- } \\
\text { mala, Guyana, Haiti, Honduras, Jamaica, Panama, } \\
\text { Peru, Saint Kitts and Nevis, Saint Lucia, Saint Vincent } \\
\text { and Grenadines, Suriname, Trinidad and Tobago, } \\
\text { Uruguay, Venezuela }\end{array}$ \\
\hline \multirow[t]{2}{*}{ South Asia } & Bangladesh, Nepal & Bhutan, India \\
\hline & 35 (I)NDCSs & 64 (I)NDCSs \\
\hline
\end{tabular}

In the sections below, we analyse the synergies that we have identified in a number of the NDCs, building on the findings of the previous chapter where we identified potential synergies in the selected sectors.

Examples of synergy effects linked to a variety of policies and strategies can be found, even though the country does not explicitly frame these as M\&A synergies. To capture as many examples as possible, we have included potential M\&A synergies based on the findings of the literature review, even if the synergy was not identified by the NDC. 


\title{
4.1 Examples of agriculture sector synergies in (I)NDCs
}

\author{
Agriculture joins energy as the sector where most parties have identified synergies or co- \\ benefits. However, more than half of the reviewed NDCs do not directly identify synergies \\ in this sector. While most Parties have identified adaptation and/or mitigation actions in \\ the agricultural sector, explicit reference to synergies is less commonly found.
}

Table 2: Soil

\section{Key synergies: Resilience, Food security}

In the context of climate change, soil is a key factor. Soil holds properties that can either enable or prohibit both mitigation and adaptation. When correctly managed, soil (incl. crops grown on the land) can sequester carbon, host biodiversity and protect against flooding and erosion. If badly managed, it can be a source of GHGs and increase susceptibility to floods and erosion. Actions to promote soil management are therefore likely to entail synergies.

The INDC of Burkina Faso notes that actions to sequester carbon in the soil will contribute to restoring degraded land and mitigating climate change, but also help preserve ecosystems and water resources, which will bring adaptation benefits.

The Tongan INDC notes that "mitigation co-benefits may result from plans to enhance the climate resilience of the agriculture sector; e.g. through improved soil management practices".

$(M \rightarrow A)$

$(\mathrm{A} \rightarrow \mathrm{M})$

Restoration of grassland and improvement of soil management practices are mentioned in several other (I)NDCSs, but not in the context of providing mitigation or adaptation co-benefits. In the Chinese INDC, actions to prevent grassland degradation and improve carbon storage in soil are identified.

India has implemented a National Initiative on Climate Resilient Agriculture to protect and stabilize ecosystems while promoting resilient cropping and farming systems to minimize risks to climate extremes, as well as increase forest/tree cover.
$(\mathrm{M} \rightarrow \mathrm{A}$
or
$A \rightarrow M)$

$(A \rightarrow M)$

\section{Table 3: Livestock}

\section{Key synergies: Food security, Labour and income}

Livestock is among the leading causes of agricultural GHG emissions. A number of African countries highlight actions on livestock with mitigation and adaptation benefits, though not explicitly referring to these as synergies.

Burkina Faso intends to improve animal welfare through greater water availability, achieved through master plans for water development and management, as well as establishing stone barriers, levees, filtering levees, terraces, half-moons, agroforestry, and dune stabilisation. At the same time, they intend to focus on improvements in feed quality, which "could likely lead to reduced methane emissions" a mitigation benefit.

Togo has similar plans to improve food and promote breeding and extensive farming, while Ethiopia focuses on the importance of livestock for local farm income and thus adaptive capacity. As agriculture sector adaptation strategies, the goal is to improve livestock production practices for greater food security while reducing emissions. 
Table 4: Ecosystem based approaches in agriculture

Key synergies: Resilience, Food security

Ecosystem-based approaches are often discussed from an adaptation perspective. These approaches acknowledge that the impacts of climate change can be limited in terms of the influence on, inter alia, biodiversity and agricultural resilience. Actions may include better monitoring, more sustainable management principles, and conservation and restoration measures.

Ecosystem-based approaches can be found in a number of NDCs, including Ethiopia, Costa Rica, Mexico, and Seychelles. In these cases, this is done explicitly through an ecosystem approach. Healthy ecosystems provide ecosystem services, such as carbon sequestration and water provision, which can have adaptation and mitigation benefits.

The Ethiopian NDC seeks to improve ecosystem health by incorporating practices such as organic farming and sustainable land management practices, which increases resilience while lowering emissions.

The INDC of Seychelles mentions the implementation of three ecosystem-based adaptation projects focussing on management of coastal ecosystems, protection of mangroves, and sustainable watershed management.

The Seychelles focus on added benefits to society such as "revitalising the extension services and also providing opportunities for young Seychellois to study climate-smart and ecosystembased approaches to agriculture, put in place programmes for sustainable industrial and artisanal fisheries, sustainable mariculture, promote home gardening, improve port infrastructure for artisanal and industrial fisheries, reduce illegal, unreported and unregulated activities; and continue to support the insurance scheme for farmers and fishers".

Another example is from the Mexican INDC, which note that ecosystem-based adaptation will have added benefits for mitigation and society at large: "In Mexico there is a large diversity of ecosystems that provide society with a vast amount of environmental services such as carbon sequestration, provision and maintenance of water, habitat conservation for the permanence of species, reduction of impacts caused by meteorological disasters, and the formation and maintenance of soils. These environmental services are seriously threatened by human activities and by the effects of climate change. Ecosystem-based adaptation consists of the conservation of biodiversity and ecosystem services as part of an integral adaptation strategy to assist human communities to adapt to the adverse effects of climate change".

$(\mathrm{A} \rightarrow \mathrm{M})$

Table 5: Early warning systems and ICT

Key synergies: Resilience, Food security

Early warning systems, climate information systems, and other ICT is mentioned by 28 Parties in the context of adaptation. As examples, Nigeria, Argentina, Gambia, and Mongolia intend to improve early warning systems, though in a context of increasing resilience and adaptive capacity.

Burkina Faso identifies early warning systems in the context of synergies, stating that meteorological data facilitate management of extreme climate events while also providing producers with "important social and economic information that makes it possible to adapt their systems of production and protect their persons, their means of subsistence, and their products".

Ethiopia seeks to reduce the incidence and impact of fire and pest epidemics on livelihoods and ecosystems through integrated pest management and early warning systems, which increase the adaptive capacity of local farmers, while avoiding loss of food and feed, providing a mitigation benefit. 
Table 6: Climate smart agriculture

Key synergies: Resilience, Food security, Labour and income

Implementing climate-smart agriculture (CSA) practices is the most mentioned type of action to promote synergies identified in (I)NDCSs. However, CSA is often not recognized in the (I)NDCS of individual Parties as containing M\&A in ter-relationships, although CSA by definition acts at the intersection of mitigation and adaption, being composed of three main pillars: "sustainably increasing agricultural productivity and incomes; adapting and building resilience to climate change; and reducing and/or removing greenhouse gas emissions, where possible" (FAO, 2013). In all, 29 Parties mention CSA, most of these being African, and a further 9 Parties make reference to CSA in the context of agro-ecological approaches.

Niger identifies that the agriculture, forestry and other land use (AFOLU) sector can show synergies through the use of CSA activities, and further recognize this in a context of food security and grassroots development. Another interesting approach is taken in Malawi, which links CSA to financing, noting that CSA practices can increase GHG mitigation, but that implement these initiatives is conditional upon support.

$(\mathrm{A} \rightarrow \mathrm{M}$ or $\mathrm{A} \cap \mathrm{M}$, depending upon specific action)

$(\mathrm{A} \cap \mathrm{M})$

Cambodia, as one of the few non-African Parties mentioning CSA, does so in a context of resilience, noting that CSA can promote climate resilient agriculture in coastal areas, and help adapt to changes in water variability.

\subsubsection{Agriculture: Adaptation with mitigation benefits}

Agriculture is mentioned in almost all (I)NDCs, and most Parties have identified adaptation and/or mitigation actions in the agricultural sector. Approximately half of the reviewed (I)NDCs mention potential synergies or co-benefits in relation to agriculture. The typical synergies identified in the agricultural sector are related to soil, livestock, and ecosystems. Most actions are primarily aimed at adaptation but have beneficial mitigation side-effects. Creating climate resilient agriculture through actions such as soil management that can protect against flooding and erosion while protecting biodiversity and sequestering carbon. These are vital adaptive actions in many developing countries to secure food production and food supply.

In the area of livestock, there is a focus on enhancing adaptive capacity through both breeding and water management, while improving production practices that all can lead to reducing emissions from livestock, improved income of farmers, and greater food security.

Ultimately, however, synergies could be yielded much more intensively in the agricultural sectors of developing countries. Simple side-benefit relations are predominant, but experience suggests many actions could be designed to provide a broader range of synergies. Explicit recognition of the potential for $\mathrm{A} \cap \mathrm{M}$ in project or programme design documents could help address this. This entails that project and programme owners design ways to realise both mitigation and adaptation benefits. A first barrier to this is the distinction between adaptation and mitigation programmes and financing. 


\title{
4.2 Examples of forestry sector synergies in (I)NDCs
}

\author{
Most reviewed (I)NDCSs have not identified synergies across mitigation and adaptation ac- \\ tions for the forestry sector. However, a number of programmes that promote reforestation \\ or afforestation have been identified. Some of these have clear M\&A synergies, though this \\ is not necessarily explicitly mentioned in the (I)NDCS of the Parties.
}

Table 7: Sustainable forest management

Key synergies: Resilience, Labour and income

Sustainable forest management (SFM) can include afforestation but also encompass a broader set of actions with mitigation and adaptation benefits. This includes a broad system perspective on actions and effects that affect the sustainability of forest management, which may include biodiversity, land degradation, job opportunities, and water conservation. It dictates a balance between the demand for forest outputs and a healthy and diverse forest.

Myanmar highlights the combined mitigation and adaptation benefits of action in the forestry sector: "Actions in the forestry sector will not only preserve one of the world's most important GHG sinks, but will also prevent soil erosion and therefore reduce the risk to the population of floods and landslides".

The Laotian INDC stresses that actions to promote sustainable forest management will improve the resilience of communities and ecosystems and at the same time reduce GHG emissions by absorbing carbon dioxide.

Sustainable Forest Management is featured in the Zambian INDC, where synergies related to adaptation as well as the general economy are described. These include increased biodiversity $(\mathrm{M} \rightarrow \mathrm{A})$ preservation, increased resource productivity leading to watershed services, ecosystem protection restoration of natural habitats, restored hydrological balance in the river basin, creation of job opportunities and alternative livelihoods contributing to rural poverty reduction, increased rural household incomes from SMEs, local community empowerment and capacity building, improved air quality, and finally, reduced GHG emissions; a perfect example of other actions leading to adaptation and mitigation co-benefits.

\section{Table 8: Integrated approaches}

\section{Key synergies: Resilience, Food security}

Integrated approaches in forest management is similar to SFM in that it applies a understanding of systems effects, such as social and economic dependencies, physical conditions, conflicts, and geographical scales. Several ecosystem approaches and natural resource management principles exists to apply increasingly integrated approaches.

An example of integrated approaches in providing M\&A synergies in the forestry sector is Bolivia, where a dedicated programme has been adopted. The goal of the "Joint Mitigation and Adaptation Mechanism for Integral and Sustainable Management of Forests" is to strengthen synergies between mitigation and adaptation climate change in the field of forests. The INDC describes the type of co-benefits achieved and links these to mitigation and adaptation, noting that "forests facilitate the provision of environmental functions, strengthen food security and livelihoods of local and national population in a complementary manner and promote timber and non-timber forest production and agroforestry systems, consolidating their contribution to development of the country. Thus forests contribute jointly to mitigation and adaptation to climate change". 
Table 9: Reducing emissions from deforestation and forest degradation (REDD+)

Key synergies: Resilience, Food security

A number of (I)NDCs of provide reference to international programmes, most notably REDD+, which is mentioned by 44 Parties. The (I)NDCs that mention REDD+ but do not refer to inter-relationships, co-benefits or synergies mainly focus on the mitigation component within REDD+, though a few, such as Suriname, do recognise the adaptation and development benefits.

For example, Nepal note that "REDD+ initiatives would contribute to promoting sustainable management of forests, carbon sequestration and adaptation co-benefits" (Nepalese INDC, p. 4), thus acknowledging that protection of forests while sequestering carbon can provide synergies by protecting against erosion, regulating climate or other local adaptation benefits.

A similar reference to synergies between reducing $\mathrm{CO}_{2}$ emissions and achieving adaptation benefits on a landscape level is found in the INDC by Paraguay, which promotes "forestry with a landscape approach in order to increase forests resilience to climate change and reduce the vulnerability of local populations".

Ghana also refer to REDD+, pointing out that such actions "may create jobs, increase the production of stable food, [and] result in biodiversity conservation". While not directly adaptation actions, $(\mathrm{M} \rightarrow \mathrm{A})$ they can nonetheless be seen as synergies of an action directed at mitigation.

\section{Table 10: Afforestation}

Key synergies: Resilience

Afforestation targets planting of new forests on lands that historically have not contained forests. From a mitigation perspective, this may increase carbon sequestration and provide benefits, such as increasing biodiversity, improving soil quality and avoiding soil degradation.

A number of noteworthy examples of afforestation (mitigation) actions with adaptation synergies include Bangladesh, where the national afforestation program has led to significant afforestation in newly accreted lands along the coast of Bay of Bengal, where new mangrove plantations play an important role in carbon sequestration while protecting against groundwater intrusion, erosion, storms, and sea level rise, a clear adaptation benefit.

The Ugandan INDC note that "tree planting, afforestation and reforestation programmes contributes to emission reduction through carbon sequestration, as well as biodiversity conservation". As improved biodiversity can increase resilience of natural ecosystems, this is an added adaptation benefit.

Another example of afforestation projects associated with other (primarily adaptation) benefits is found in Burkina Faso's INDC, which describes synergies associated with forests projects, in terms of "projects to create forests and develop natural forests make it possible to conserve soil and water, reduce erosion and air pollution and conserve biological diversity, to say nothing of providing ligneous and non-ligneous forest products, including those used for foods and medicines".

This is also the case in Tonga, where the National Forest Policy is important in terms of adaptation and mitigation synergies: "A suite of activities regarding forest preservation, forest management and regulation are planned, in alignment with Tonga's resilient development strategy".

Further, Mexico and Ecuador disclose zero deforestation rate goals, but does so in the adaptation section of the INDC, indicating that this target should be seen not only in the context of re$(\mathrm{M} \rightarrow \mathrm{A})$ ducing emissions, but also upholding adaptation capacity. 
Table 11: Agroforestry

Key synergies: Resilience, Labour and income

Agroforestry is an integrated system combining agriculture and forestry to create diverse, productive, and sustainable land-use systems by growing trees and shrubs around or among pastures or fields. When correctly implemented, the literature suggests agroforestry systems bring adaptation benefits, including protection against floods, increased water retention capacity while simultaneously generating mitigation actions, such as carbon storage, decrease in loss of soil organic matter benefits $\left(\int(M, A)\right)$.

Overall, 22 Parties provide reference to agroforestry in relation to adaptation, while 15 provide reference to agroforestry in relation to mitigation.

Burkina Faso, Rwanda, Zimbabwe, and Bolivia, provide reference to agroforestry systems in the context of synergies. However, none of the (I)NDCSs describe if and how agroforestry systems should be promoted and it is not explained what kind of synergies can be expected.

The Rwandan INDC notes co-benefits to the general economy, such as job creation and lower charcoal costs.

$\left(\int(M, A)\right)$

Interestingly, India has implemented a National Agroforestry Policy, which aims at encouraging and expanding tree plantation with crops and livestock, but does not highlight this as an example of such.

\subsubsection{Forests: Few synergies, little REDD+, no JMA}

Regarding forest sector synergies, most reviewed (I)NDCs have not identified synergies across mitigation and adaptation actions. However, promotion of reforestation or afforestation are mentioned in a number of (I)NDCs, with some indicating the synergistic effects. Sustainable forest management is described in several (I)NDCs as providing both resilience, labour, and income. It was also emphasised that there are three types of actions that are prevalent in (I)NDCs, namely REDD+, CSA, and agroforestry.

\subsection{Examples of energy sector synergies in (I)NDCs}

The identified actions that provide synergies in the energy sector relate to renewable energy, mostly in terms of bioenergy. Several actions with potential to deliver both adaptation and mitigation have been identified, but these are rarely presented in a context of synergies. 
Table 12: Renewable and low carbon energy

Key synergies: Energy security, Labour and income

As a general mitigation action in the energy sector, which may encompass a number of actions under the same definition, the use of renewable or low-carbon energy sources is mentioned in several (I)NDCSs. These actions also deliver additional adaptation benefits $(\mathrm{M} \rightarrow \mathrm{A})$.

Reference is made by Burkina Faso and Rwanda to economic benefits and general development, stating that renewable electricity (solar PV and hydropower) will create jobs and increase the adaptive capacity of local communities.

The welfare component is highlighted in more specific terms by Niger in that "the co-benefits in the energy sector relate to improvement in the people's living conditions as a result of increased income through social welfare, access to potable water, education and health, as well as access to new information and communication technologies (NICT) and energy equipment, development of local entrepreneurship, alleviation of women's domestic duties and reduction of the rural exodus through job creation".

A parallel synergy, in Burkina Faso's INDC, emphasise that renewable energy can cut energy costs, increasing the productivity.

$(\mathrm{M} \rightarrow \mathrm{A})$

$(\mathrm{M} \rightarrow \mathrm{A})$

$(\mathrm{M} \rightarrow \mathrm{A})$

The most prevalent action that bridges adaptation and mitigation relate to the use of biofuels and bioenergy in general. Plans to expand the use of biofuels can be found in national policies in across a range of countries, including Malaysia, Mozambique, and India. However, explicit links to adaptation are not made, meaning they are not identified as synergies.

A notable example of a project within bioenergy that recognizes links to other sectors and to ad$(\mathrm{M} \rightarrow \mathrm{A})$ aptation is found in Burkina Faso, where the plan to increase the use of biogas systems will have the added benefit of also providing organic fertilizers, which will boost food production.

Rwanda's Sustainable Small Scale Energy installation program is interesting in that it highlights added benefits, such as "additional income generating activities for communities" and "contribute to the success of forestry management programmes where wood fuels [e.g. for cooking stoves] are replaced by electricity".

Rwanda notes that "promotion of environmentally sustainable use of biomass fuels will result in reduced deforestation and reduced indoor air pollution" and improve revenues and quality of life.

$(\mathrm{M} \rightarrow \mathrm{A})$

$(\mathrm{M} \rightarrow \mathrm{A})$

Table 13: Hydropower

Key synergies: Resilience, Energy security, Labour and income

Hydropower, as a specific mitigation action, can provide significant synergies. However, hydropower can also have negative consequences to biodiversity, rural livelihoods, and downstream water users, among others. Such aspects should therefore be carefully considered, as the trade-offs might be bigger than the perceived benefits. This is a point stressed by Leonard et al. (2016) in their article on M\&A synergies in the agriculture and forest sector.

Hydropower is presented in a number of (I)NDCSs, including Laos and Rwanda, as an action that $\quad(M \rightarrow A)$ delivers adaptation benefits parallel to mitigation.

More specifically, Laos's INDC highlight that "hydroelectricity has great potential in Lao PDR providing clean energy, an opportunity to reduce GHG emissions and also meet other objectives such as flood, irrigation and water supply", further stating that, "the rural electrification programme will [...] promote rural development and reduce poverty". 


\section{Table 14: Energy access}

Key synergies: Energy security, Labour and income

Improved energy access and decreasing energy poverty hold important mitigation and adaptation possibilities, in parallel to many other policy goals. While not framed in a context of adaptation, but often discussed more generally in terms of energy security and economic development, energy access is discussed in several (I)NDCSs, such as by India and Ghana. Energy development and access to energy, especially bioenergy, can be seen as a mitigation action, but bring the added benefit of increasing people's adaptive capacity.

Reference to energy access as an added benefit is mentioned in a few (I)NDCSs, including Bangladesh, India, Ghana, and Swaziland, with the latter explicitly referring to this synergy as particularly "relevant in the context of the current challenges experienced in the regional electricity system."

Table 15: Jobs and economic benefits

\section{Key synergies: Energy security, Labour and income}

The link between energy consumption, emissions of carbon dioxide and economic development has traditionally been very strong, which in most regions and instances still holds true. Moreover, the energy sector may typically represent an important part of the economy. Hence, mitigation actions influence jobs and the overall economy, and are referred to in several (I)NDCSs in relation to energy co-benefits.

In Ghana, scaling up renewable energy penetration creates job opportunities and increase （predominately electricity access while resulting in "avoided kerosene subsidy savings and kerosene savings". $\quad M \rightarrow A$ )

\section{Table 16: Air quality}

Key synergies: Health

A prevalent synergy for many lower-income countries relate to air quality improvements. As a commonly discussed action in this field in terms of single individual health and predominantly that of women and children, cook stoves receive significant attention. Naturally, however, several other links exists between mitigation, adaptation and other policy goals. Examples of this include energy access that may reduce small scale combustion and large scale combustion associated with appropriate air pollution control technologies.

Cook stoves are mentioned in the (I)NDCs of Zambia, Rwanda, and Ghana, with the latter tying a link to M\&A synergies by noting that adoption of market-based cleaner cooking solutions will save woodland from degradation, while reducing indoor pollution resulting from wood fuel usage and smoke-related respiratory and eye diseases. This is a clear example of the fourth type of inter-relationship, $A \cap M$, as the focus is on a different action (clean cook stoves), but with clear adaptation and mitigation synergies.

Burkina Faso identified improved cook stoves as expected to not only reduce emissions, but also to "reduce exposure to respiratory diseases caused by smoke or the inhalation of carbon dioxide or carbon monoxide".

In a general perspective, Bangladesh states that mitigation options in the energy sector "are expected to have co-benefits, such as improved air quality from increased renewables and improved access to energy, e.g. from localised biogas production". 


\subsubsection{Energy sector: Mostly mitigation and economic side benefits}

Several actions with potential to deliver both adaptation and mitigation have been identified in the (I)NDCs, but these are rarely presented in a context of synergies. Identified synergies tend to be related to renewable energy, mostly in terms of bioenergy, but also solar and water in terms of income and energy security. Micro generation and cleaner cooking facilities instead of open fires are actions that also provide better health conditions while protecting of forest.

Energy is the sector with the least consideration of adaptation. As most investments and programmes justify their climate relevance in terms of reducing emissions, adaptation benefits are often overlooked. A first requisite for realising synergies is therefore a systematic consideration of adaptation side effects in the energy sector. Job creation and security of supply is, although desirable and valuable, not considered climate adaptation benefits in this study.

\subsection{Examples of urban sector synergies in (I)NDCs}

Urban systems make up a complex web of systems with a range of potential synergies across infrastructures incorporated in urban environments. However, as can be seen below, very few (I)NDCs highlight the urban context. That does not imply that the potential for synergies that lies in the urban infrastructures are neglected. Rather, many of the previous sectors' synergies may apply in urban or peri-urban contexts, despite not being specified in this spatial denomination.

An important aspect in relation to synergies in this sector is the urban metabolism, related to the resource intensity of urban areas. Sustainable solutions must acknowledge the potential of conflicts in local ecosystems in providing the necessary goods and services needed. This includes, inter alia, local biofuels and other renewables, local food production, and urban ecosystem services.

In addition to the identified synergies in the (I)NDCs, examples of other potential synergies in urban policies may include building weatherisation that can also improve energy efficiency and storm resilience. Urban micro grids and distributed renewables provide local low-carbon solutions that increase the resilience of the power system. Moreover, increasing urban green areas provides several synergies, in parallel to mitigation, such as reducing urban heat islands, storm water capacity, urban ecosystem services, improved air quality and recreation. A last example, which emphasises the wide variety and scale of synergistic solutions is to elevate subway ventilation grates to protect an energy efficient transport system. 
Adopting effective waste management strategies provide potential for biogas production and fertilisers, where the latter can increase agricultural yields, as well as reducing decomposition and methane emissions directly to the atmosphere. Better waste management may also result in improved resource efficiency with broad positive effects on material flows.

As a specific example, which adds synergies in addition to the above, Ghana highlight synergies $\quad(M \rightarrow A)$ in terms of creating jobs and improving urban sanitation.

\section{Table 18: Transportation}

Key synergies: Labour and income, Health

Improved transportation systems that allow low-carbon, energy efficient, low-congestion and mass transport, creates mitigation possibilities while also improving mobility and access to jobs.

\section{Key synergies: Resilience}

Flood risks can have severe impacts, affecting key infrastructures (energy, roads, water etc). Planning for actions to reduce the risks needs to account for the potential risks and hazards, hydrology, environmental impacts, health issues and result in flood protection schemes.

In terms of urban areas in coastal zones, Burkina Faso identifies that investments in understand ing flood-risks to "...make it possible to promote architecture that is adapted to climate change

$(A \rightarrow M)$ conditions, [with an] emphasis on local materials and savings of wood resources, which strengthens conservation of forests and biodiversity".

\subsubsection{Urban sector: Not much mitigation or adaptation in the first place}

Very few (I)NDCs mention the urban context, let alone identify synergies. Whereas the synergistic thinking is much more common in the other sectors, the emergence of megacities and the general migration from rural areas to urban areas in developing countries should justify explicit consideration of both adaptation and mitigation in urban settings.

Our review of potential synergies in relation to urban areas further shows that there are a number of positive effects to benefit from such as health, resilience, improved labour and income, energy security through improved transportation, waste management and ICT systems. Given the scope of urbanisation and the cross-cutting nature of the sector, there is potential to promote synergies. 


\subsection{Crosscutting: CSA, REDD+ and agroforestry}

Three general actions, which are prevalent in the (I)NDCs are worth discussing in more detail; namely, REDD+, Climate Smart Agriculture (CSA) and agroforestry.

Concerning REDD+, all Parties acknowledge the mitigation component of actions under REDD+ and some acknowledge the adaptation possibilities $(M \rightarrow A)$. However, though some consider synergies, there is a need to consider these in unison $\left(\int(M, A)\right)$, as the full range of benefits will otherwise not be realised.

As is noted by Leonard et al. (2016), the links between REDD+ and adaptation "could benefit from further policy development aimed at realizing the benefits, whilst also safeguarding against negative impacts and managing trade-offs." In this context, however, the REDD+ project can negatively impact on the adaptive capacity of local people if not implemented correctly (Locatelli et al., 2011; Leonard et al., 2016). This would be the case if land rights are lost or the forest as a basis for livelihood is otherwise lost. The "plus" in REDD+ denotes that more than mitigation (M) is intended, and the synergies between reducing emissions through maintaining forest cover and the benefits to livelihoods and adaptive capacity should be explored further.

Climate Smart Agriculture is the most frequently mentioned action to promote synergies identified in (I)NDCs. However, there is limited evidence that (I)NDCs of individual Parties recognise CSA as holding M\&A inter-relationships. They see CSA mostly as having adaptation and mitigation benefits $(A \cap M)$ rather than designing the actions to improve synergies across the two $\left(\int(M, A)\right)$. This side-by-side approach exists despite the definition of CSA pointing to links of mitigation and adaption, being composed of three main pillars: "sustainably increasing agricultural productivity and incomes; adapting and building resilience to climate change; and reducing and/or removing greenhouse gas emissions, where possible" (FAO, 2013).

Agroforestry, which involves integrating trees into agriculturally productive landscapes, brings adaptation and mitigation benefits. Potential for synergies is ripe, as seen through the benefits of agroforestry: increased access to dietary diversity, as a means for reducing undernutrition; safety net and resilience in an increasingly erratic climate, providing foods all year round and also when annual crops fail; enriched asset base of poor households; and improved soil fertility and livestock productivity on farms, among others (ICRAF, 2016).

An important aspect in terms of agroforestry is that none of the (I)NDCSs describe if and how agroforestry systems should be promoted and it is not explained what kind of benefits can be expected (i.e. examples above of benefits are not drawn from (I)NDCSs). Thus, actions have clearly not been designed with adaptation and mitigation synergies in mind, despite agroforestry being an important avenue to explore mitigation and adaptation benefits in the agriculture and forest sectors. 


\subsection{Summary}

\subsubsection{Overview of sectoral consideration of synergies}

The table below outlines observations on synergy taken from the sectoral conclusions.

Table 20: Overview of mitigation, adaptation and synergies in sectors considered

$\begin{array}{lllll}\text { Sector } & \text { Mitigation } & \text { Adaptation } & \text { Synergy } & \text { Comment } \\ \text { Agriculture } & \text { Some } & \text { Widespread } & \text { About half } & \text { Mostly side-effects or co-benefits } \\ \text { Forest } & \text { Many } & \text { Some } & \text { None } & \text { JMA, REDD+ not often mentioned } \\ \text { Energy } & \text { Many } & \text { None } & \text { None } & \text { Economic side effects mentioned } \\ \text { Urban } & \text { Little } & \text { None } & \text { None } & \text { Many opportunities to promote synergies } \\ \text { Ecosystem } & \text { Some } & \text { Some } & \text { Only general } & \text { Synergies mentioned in a few cases but very general }\end{array}$

\subsubsection{Overview of synergies}

In Table 22 below, the identified potential synergies in the (I)NDCs are outlined according to the sectors, the actions and the nature of the synergy. 
Table 21: Summing up synergies found in the (I)NDCs according to sectors

\begin{tabular}{|c|c|c|c|}
\hline Sector & Action & Key synergies & Synergy type \\
\hline Agriculture & Soil & $\begin{array}{l}\text { Resilience } \\
\text { Food Security }\end{array}$ & $\mathrm{M} \rightarrow \mathrm{A}$ and $\mathrm{A} \rightarrow \mathrm{M}$ \\
\hline Agriculture & Livestock & $\begin{array}{l}\text { Food security } \\
\text { Labour and income }\end{array}$ & $A \rightarrow M$ \\
\hline Agriculture & $\begin{array}{l}\text { Ecosystem based approaches } \\
\text { in agriculture }\end{array}$ & $\begin{array}{l}\text { Resilience } \\
\text { Food security }\end{array}$ & $\mathrm{A} \rightarrow \mathrm{M}$ and $\mathrm{A} \cap \mathrm{M}$ \\
\hline Agriculture & Early warning systems and ICT & $\begin{array}{l}\text { Resilience } \\
\text { Food security }\end{array}$ & $\mathrm{A} \cap \mathrm{M}$ \\
\hline Agriculture & Climate-smart Agriculture & $\begin{array}{l}\text { Resilience } \\
\text { Food security } \\
\text { Labour and income }\end{array}$ & $\mathrm{A} \rightarrow \mathrm{M}$ or $\mathrm{A} \cap \mathrm{M}$ \\
\hline Forestry & $\begin{array}{l}\text { Sustainable Forest Manage- } \\
\text { ment }\end{array}$ & $\begin{array}{l}\text { Resilience } \\
\text { Labour and income }\end{array}$ & $\mathrm{M} \rightarrow \mathrm{A}$ and $\mathrm{A} \cap \mathrm{M}$ \\
\hline Forestry & Integrated approaches & $\begin{array}{l}\text { Resilience } \\
\text { Food security }\end{array}$ & $\int(M, A)$ \\
\hline Forestry & Afforestation, REDD+ & $\begin{array}{l}\text { Resilience } \\
\text { Food security }\end{array}$ & $\mathrm{M} \rightarrow \mathrm{A}$ \\
\hline Forestry & Agroforestry & $\begin{array}{l}\text { Resilience } \\
\text { Labour and income }\end{array}$ & $\mathrm{M} \rightarrow \mathrm{A}$ and $\int(\mathrm{M}, \mathrm{A})$ \\
\hline Energy & $\begin{array}{l}\text { Renewable and low-carbon en- } \\
\text { ergy }\end{array}$ & $\begin{array}{l}\text { Energy security } \\
\text { Labour and income }\end{array}$ & $\mathrm{M} \rightarrow \mathrm{A}$ \\
\hline Energy & Biofuels and bioenergy & $\begin{array}{l}\text { Energy security } \\
\text { Labour and income }\end{array}$ & $\mathrm{M} \rightarrow \mathrm{A}$ \\
\hline Energy & Hydropower & $\begin{array}{l}\text { Resilience } \\
\text { Energy security } \\
\text { Labour and income }\end{array}$ & $M \rightarrow A$ \\
\hline Energy & Energy access & $\begin{array}{l}\text { Energy security } \\
\text { Labour and income }\end{array}$ & $\mathrm{M} \rightarrow \mathrm{A}$ \\
\hline Energy & Jobs and economic benefits & $\begin{array}{l}\text { Energy security } \\
\text { Labour and income }\end{array}$ & $M \rightarrow A$ \\
\hline Energy & Air quality & Health & $\mathrm{M} \rightarrow \mathrm{A}$ and $\mathrm{A} \cap \mathrm{M}$ \\
\hline Urban & Waste management & $\begin{array}{l}\text { Energy security } \\
\text { Health }\end{array}$ & $M \rightarrow A$ \\
\hline Urban & Transportation & $\begin{array}{l}\text { Labour and income } \\
\text { Health }\end{array}$ & $A \cap M$ \\
\hline Urban & Flood risks & Resilience & $A \rightarrow M$ \\
\hline
\end{tabular}


It should be noted that we did not identify any specific mention of urban sector synergies in the (I)NDCs. The urban sector synergies in Table 22 therefore reflects the potential synergies based on the concepts identified in the review of the literature that align with the sectors in the (I)NDCs. As already mentioned, some of these synergies could be categorised within other sectors and such synergies can also be found in the (I)NDCs but are not recognised as having synergistic effects.

\subsubsection{Highlighting key NDCs}

Burkina Faso proposes actions such as carbon sequestration in soil that also provide resilience and preserving eco-systems $(M \rightarrow A)$; improved water management and feed quality in relation to livestock $(A \rightarrow M)$; ICT early warning systems and meteorological information that also would improve social and economic conditions in broader terms ( $A \cap M)$; Afforestation programmes $(M \rightarrow A)$; promotion of agroforestry $(M \rightarrow A)$; renewable energy and bioenergy with focus on the potential of cutting energy cost increasing productivity and providing for instance organic fertilisers $(M \rightarrow A)$; sustainable flood risk systems $(A \rightarrow M)$; Improving air quality through cleaner cooking stoves $(A \cap M)$.

From the review of the (I)NDCs, it should be highlighted that parties tend to point to the potential synergies in more generic terms. For instance, the Ethiopian INDC seeks to maximise the synergies between adaptation and mitigation, especially in agriculture and forests. In similar fashion, Peru states that "it is necessary to continue and increase the promotion, development and implementation of complementary and synergistic actions of mitigation and adaptation."

A noteworthy example of an INDC considering M\&A synergies can be found in the Ecuadorian INDC, which states that "proposed adaptation activities promote positive synergies with mitigation actions." In addition, despite not including specific actions on M\&A synergies, Ecuador recognises that "several adaptation activities will be beneficial to enhancing efforts on mitigation. [...] For instance, the protection of water basins will not only avoid landslides and erosion processes related to torrential rain, but will also preserve agriculture and livestock production, water availability for human consumption, and ecologic water flows that work as a driving engine of numerous hydroelectric plants."

Further to this, Costa Rica expresses its wish to explore synergies between its ecosystem-based adaptation and mitigation through actions to avoid deforestation, in that "Costa Rica is committed to develop its adaptation practice from an ecosystem based adaptation focus, building on the commitment to increase forest coverage to $60 \%$. At the same time, there are opportunities for exploring synergies between adaptation practices and the reduction of emissions through avoided deforestation." 



\section{Identification of elements in the Paris Agreement with positive bearing towards M\&A synergies}

This section analyses the policy mechanisms contained in the Paris Agreement that could potentially support or act as barriers for $\mathrm{M} \& \mathrm{~A}$ synergies.

The Paris Agreement and the accompanying decisions promoting its further development symbolise a new pledge-and-review approach to global climate change deals. Under this framework, parties can determine their contribution at a national level. Compared to the predecessor, the Kyoto Protocol (KP), the Paris Agreement provides a clearer system for comparing and monitoring progress.

The Paris Agreement, like its predecessor the Kyoto Protocol, does not favour or single out specific sectors as more important than others. ${ }^{10}$ Both the Agreement and the Protocol are sector-, technology- and action neutral. Any support for synergy between mitigation and adaptation is to be found in targets, reporting systems, rules for finance and technology transfer - and in the collective thinking behind the structure of the agreement.

This chapter reviews the wording of the text of the Agreement for how adaptation and mitigation synergy is described. The analysis identifies where the individual policy mechanisms and obligations could support synergy between mitigation and adaptation, drawing on the types of M\&A synergy used outlined in the review of the literature and examples where it has been implemented in practice.

\subsection{M\&A synergies in the purpose of the Agreement and the Decision}

International treaties and agreements are, by nature, a series of compromises based on delicate negotiation. This is reflected in the wording of the Paris Agreement.

The preamble of the Paris Agreement stresses the central importance of climate change actions, responses and impacts for equitable access to sustainable development and eradication of poverty. This implies that climate change policies and measures for both mitigation and adaptation have the potential to advance sustainable development objectives, and even more so in case of better integration of mitigation and adaptation synergies.

${ }^{10}$ Except for the dedicated paragraphs on LULUCF in the KP (Article 3.3 and 3.4) which to some extent is mirrored in the Paris Agreement (Article 6). 
Article 2 of the Paris Agreement sets out what it intends to achieve, and para 1 (b) gives a first indication of need to co-consider mitigation and adaptation: "Increasing the ability to adapt to the adverse impacts of climate change and foster climate resilience and low greenhouse gas emissions development, in a manner that does not threaten food production."

This formulation does not necessarily cater for synergies, but it links increased climate resilience and adaptation to the need to de-couple growth and GHG emissions. This breaks down the traditional dichotomy of adaptation and mitigation as two separate domains and encourages integrated approaches at higher policy levels. It can thus be seen as facilitating, but not ensuring, more synergy.

In the preamble of the decision, this intention is not clearly mirrored. The decision welcomes the UNGA resolution on Sustainable Development, which arguably includes both adaptation and mitigation aspects. Yet the only mention of adaptation and mitigation is found in the third last preamble, where it is mentioned that early action may lead to major reductions in cost later on for both mitigation and adaptation. This in itself, however, does not constitute explicit support for synergy. Ultimately, the Paris Agreement suggests an opportunity integrated M\&A approaches without calling for them directly. It provides a degree of flexibility in the financing guidelines, with sufficient scope for stakeholders to make explicit demands for close linkages between mitigation and adaptation.

\subsection{Types of M\&A found in the Agreement and its decision}

\subsubsection{Adaptation OR Mitigation}

Mitigation or adaptation is highlighted throughout both the Paris Agreement and the Decision texts, with an emphasis on mitigation reflecting the global drive to reduce GHG emissions. There are at least three clear examples of wording in the Paris Agreement that iterates one-way link between $M$ and $A$, i.e. the $M \rightarrow A$ or $A \rightarrow M$ link.

- Paris Agreement Article 4(7) mentions one-way co-benefits from adaptation action: "Mitigation co-benefits resulting from Parties' adaptation actions and/or economic diversification plans can contribute to mitigation outcomes under this Article."

- And in Paris Agreement article 7(4) on adaptation it reads "Parties recognize that the current need for adaptation is significant and that greater levels of mitigation can reduce the need for additional adaptation efforts, and that greater adaptation needs can involve greater adaptation costs." The latter establishes the link between mitigation and adaptation, but not in terms of co-benefits. It rather sets out that more mitigation leads to less need for adaptation, which can hardly be interpreted as a co-benefit.

- The last case is found in para 108 of the decision on enhanced action prior to 2020. Here, the parties recognize the "social, economic and environmental value of 
voluntary mitigation actions and their co-benefits for adaptation, health and sustainable development". The co-benefits of mitigation action for adaptation is an example of $\mathrm{M} \rightarrow \mathrm{A}$.

These examples are identified based on the use of the terms adaptation and mitigation. There are other examples where the terms are used. In the context of transparency of support and action in the Decision (namely in para 94(c)), the AWG-PA is requested to consider reporting on adaptation action and planning when developing modalities, procedures, and guidelines (MPGs) for accounting and review of action. The MPGs serve the purpose of ensuring consistency, comparability, comprehensiveness of reporting, and accounting on mitigation action, Therefore, the link established by 94 (c) appears to be $\mathrm{A} \rightarrow \mathrm{M}$.

However, quite interestingly, in the mitigation articles of the Decision giving effect to the Paris Agreement (Paragraphs 22-40), adaptation is only mentioned once (para 39), despite elaborating guidance on accounting for nationally determined contributions (para 27-31). Listing M\&A synergies would have supported awareness for increased consideration. The near omission could be attributed to the current knowledge on the synergies, which might simply be too sparse. Clearly, a better understanding of the linkages is needed.

It is worthwhile noting that in the corresponding articles of the decision on adaptation, no mentioning of mitigation is found, even in the para (42) concerning the modalities to be drawn up by the Adaptation Committee and the LDC expert group.

\subsubsection{Adaptation AND Mitigation}

Across both agreement and decision, the wording "mitigation and adaptation" is used commonly, though each is mentioned individually throughout the text. This listing indicates two equals, but gives no indication of any parties being expected to ensure any intended added value deriving from adaptation and mitigation. One example of this is contained in the Paris Agreement: "It shall do so in a comprehensive and facilitative manner, considering mitigation, adaptation and the means of implementation and support, and in the light of equity and the best available science."

This suggests an equal but separate consideration of mitigation and adaptation, alongside a number of other aspects, but gives no encouragement or obligation to consider added value of synergies between mitigation and adaptation. Similar examples are found in the Paris Agreement, Article 10(2), where it reads "Parties, noting the importance of technology for the implementation of mitigation and adaptation actions under this Agreement and recognizing existing technology deployment and dissemination efforts, shall strengthen cooperative action on technology development and transfer." This again places mitigation and adaptation side by side, though many technology choices could have both mitigation and adaptation benefits, including infrastructure, irrigation systems, and energy technology. 


\subsubsection{M\&A synergies?}

One clear example where the mitigation and adaptation are mentioned side-by-side, but where one can infer some anticipated added value, is under finance in para 52 of the decision. It reads: "in the implementation of the Agreement, financial resources provided to developing country Parties should enhance the implementation of their policies, strategies, regulations and action plans and their climate change actions with respect to both mitigation and adaptation to contribute to the achievement of the purpose of the Agreement as defined in its Article 2." This suggests that mutual consideration of both $M$ and $A$ is envisaged.

In the Paris Agreement, in both article 9(4) on Finance and article 10(6) on technology transfer, the phrasing "a balance between adaptation and mitigation." While this does not necessarily mean integration of the two, it does indicate that the adaptation and mitigation should be considered at the same time in the policy and financing planning process. As such, under finance and technology transfer, the Paris Agreement seems to suggest exploration of $M \& A$ synergies (i.e. $A \cap M$, as actions in other sectors can deliver adaptation and/or mitigation benefits).

In three cases, the wording indicates a deliberate aspiration to integrate mitigation and adaptation or achieve co-benefits from their combined implementation (i.e. $\int(M, A)$ ).

In article 6(1) under voluntary cooperation, parties recognise that cooperation could lead to higher levels of ambitions "in their mitigation and adaptation actions and to promote sustainable development and environmental integrity." This synergistic approach, where sustainable development, environmental integrity and M\&A goes hand in hand to ensure that $2+2$ equals 5 . As such, this paragraphs recognise the M\&A synergy potential, but it should be noted that the article is no obligation for either action, reporting, or policies. Joint Mitigation and Adaptation Approaches for the integral and sustainable management of forests (JMA) and the potential M\&A integration is also reflected in the corresponding para 54 of the decision. ${ }^{11}$

In the decision para 39 on mitigation, SBST is requested to undertake a work programme under article 6(8) with the objective of considering "how to enhance linkages and create synergies between, inter alia, mitigation, adaptation, finance, technology transfer and capacity building." This is a very clear example of integration of the synergy thinking into the agreement, and indicates more work could and should be done on this matter.

The last clear case also contains explicit wording on synergies: In article 5 (2), it reads "and alternative policy approaches, such as joint mitigation and adaptation approaches for the integral and sustainable management of forests." The wording is found in the context of an encouragement to take action and sector-wise limited to sinks, in this case forests. The JMA is listed next to REDD, which includes both mitigation and adaptation benefits in the land use sector, which is the most clear support in the Paris Agreement is found for M\&A synergies.

${ }^{11}$ GEF climate change projects cover full-size, medium-size, and enabling projects. 


\subsection{Summary}

How does the Agreement enable M\&A synergies? The enabling of M\&A synergies is not a major objective for the Paris Agreement. Synergies do not feature in any obligation or requirement set under the agreement. The links between adaptation and mitigation are often explicit in the text, although mostly as co-mentioning without any further emphasis on synergies or co-benefits.

As described, much of the text on NDCs or the systems for transparency is silent on synergies. The below table gives an overview of the elements of the agreement and the decision that includes references to synergies, alongside a clarification of the type of mitigation and adaptation relation expressed in that element.

\begin{tabular}{|c|c|c|c|}
\hline Element & Paris Agreement & Decision & Synergy type \\
\hline Purpose & Article 2 , para $1 \mathrm{C}$ & - & $\begin{array}{l}\text { Stipulates that adaptation and low emission develop- } \\
\text { ment should be ensured }\end{array}$ \\
\hline $\begin{array}{l}\text { NDCs and mitiga- } \\
\text { tion }\end{array}$ & Article 4 & Ch. III, para 22-40 & $\begin{array}{l}\int(M, A) \text { as synergy is mentioned in decision para } 39 \text {, and } \\
\text { also } A \rightarrow M \text { as mitigation co-benefits from } A \text { is men- } \\
\text { tioned in Paris Agreement } 4(7)\end{array}$ \\
\hline Adaptation & Article 7 & Ch. III, para 41-46 & $\begin{array}{l}M \rightarrow A \text {, but in the terms that increased } M \text { may reduce } \\
\text { need for } A\end{array}$ \\
\hline Finance & $\begin{array}{l}\text { Article 9, but no } \\
\text { clear mentioning } \\
\text { of } M \& A \text { synergies }\end{array}$ & Ch. III, para 52-64 & $\begin{array}{l}\text { A couple of examples of } \int(M, A) \text { in policy design and im- } \\
\text { plementation }\end{array}$ \\
\hline $\begin{array}{l}\text { Technology trans- } \\
\text { fer }\end{array}$ & Article 10 & $\begin{array}{l}\text { Ch. III, para } 65-70 \text {, } \\
\text { but no mention- } \\
\text { ing of M\&A syner- } \\
\text { gies }\end{array}$ & $\begin{array}{l}\text { No classified, as it talks of a balance in support between } \\
\text { mitigation and adaptation }\end{array}$ \\
\hline Capacity building & $\begin{array}{l}\text { Article } 11 \text {, but no } \\
\text { mentioning of } \\
\text { M\&A synergies }\end{array}$ & $\begin{array}{l}\text { Ch. III, para } 71-83 \text {, } \\
\text { but no mention- } \\
\text { ing of M\&A syner- } \\
\text { gies }\end{array}$ & No synergy \\
\hline Global stocktake & Article 12 & Para 99-101 & No synergy \\
\hline $\begin{array}{l}\text { System of trans- } \\
\text { parency }\end{array}$ & $\begin{array}{l}\text { Article } 13 \text {, but no } \\
\text { mentioning of } \\
\text { M\&A synergies }\end{array}$ & Para 84-98 & $\begin{array}{l}\text { A action to be reported in elsewise } M \text { focused reports: } \\
\text { Does not qualify as synergy }\end{array}$ \\
\hline Pre2020 action & - & Para 108 & $\begin{array}{l}\mathrm{M} \rightarrow \mathrm{A} \text {, as mitigation co-benefits for adaptation is rec- } \\
\text { ognised }\end{array}$ \\
\hline
\end{tabular}


Based on the text, some examples of potential for synergies exist. These clear examples concern different parts of the agreement and do not indicate of a coherent and deliberate approach to enabling synergies:

- Synergies are encouraged in forest action under the JMA (and REDD+).

- $\quad$ SBSTA are to develop a work programme that can enhance and create synergies between $M$ and $A$, with a mandate given in the context of NDCs and mitigation.

A more overall reading of the texts indicates that awareness of synergies was likely present among negotiators and that the agreement takes a first step towards enabling and promoting synergies.

Ultimately, it can be concluded that the Paris Agreement and the decision does not specifically promote or facilitate synergies in agriculture, energy or urban sectors. Yet it does consider ecosystem approaches as an inherent part of the encouraged action covered by article 5 and 6 in the text of the Agreement. Synergies in the forest sector is explicitly mentioned with the JMA. However, this is one among several potential nonmarket approached and currently mainly supported by a minority of parties, championed by Bolivia. 


\section{Examination of current climate funding criteria}

Traditionally, climate finance has been geared towards either mitigation or adaptation, and few funding instruments have explicitly promoted M\&A synergies. While cross-cutting projects and programmes promote actions across these fields, our review did not identify specific instruments that aim to generate M\&A synergies. Nevertheless, latent potential exists for re-orienting the existing programme architecture towards the promotion of synergies between mitigation and adaptation.

This chapter reviews the extent to which current climate finance criteria are geared towards potential M\&A synergies and what can be done to further promote such synergies. When assessing the funding criteria of selected climate funds, a two-step approach has been applied for addressing whether the funds have an explicit mandate and objective in terms of synergies between mitigation and adaptation. Eligibility and funding criteria were reviewed for explicit requirements for information on synergies and or/co-benefits, and to which extent applicants or grantees are requested to report on synergies.

The review also applied M\&A synergies concepts to analyse how current funding criteria eventually could be tailored to promote synergies in the financing of (I)NDCs and related projects.

The approach involved a desk study assessing the current funding criteria across the funds. The findings were supplemented and validated through consultations with representatives of participating climate funds and feedback received at the Nordic $\mathrm{Fi}_{-}$ nance Day at COP22 on 16th November, 2016.

The funding criteria analysis included the following funds:

- Green Climate Fund (GCF).

- Least Developed Countries Fund (LDCF).

- Special Climate Change Fund (SCCF).

- Global Environmental Facility (GEF).

- Climate Investment Funds (CIF).

- Clean Technology Fund (CTF).

- Special Climate Fund (SCF). ${ }^{12}$

- Nordic Development Fund and in particular the Nordic Climate Facility, and Nordic bilaterals (Finland, Norway, Sweden, Denmark). 
Our review focused on the project planning cycle, examining strategic level requirements, funding targets, eligibility criteria, and operational processes. In our review, we found limited requirements for information on this issue in the climate funds primarily addressing mitigation. Potential synergies exist at the strategic level (GCF, GEF), though have not materialized into specific fund investment criteria or at a project level. When not requested as an explicit criteria or an explicit reporting obligation, the opportunity for receiving monitoring and reporting information on synergies is also missed.

For mitigation projects that may affect adaptation actions, wide discretion is left to the applicants/grantees whether to actually mention adaptation, vulnerability, and climate resilience aspects in investment projects. Often, reference is only made to the extent that the project is consistent with the relevant national climate change mitigation and adaptation strategy/action plan without being specific about the adaptation/vulnerability dimension.

The table below outlines the funds examined and outlines linkages to strategies to promote synergies between mitigation and adaptation. For many of the funds, the linkages exist as potential opportunities or enablers at a strategic or operational level, though no explicit reference is made to synergies. Nevertheless, the review finds that the Funds' structures allow for synergies to be further generated within the existing framework. The table below offers a brief summary, with detailed analysis contained in Annex A. 
Table 23: Overview of green financing criteria

UNFCCC Green Climate Fund (GCF)

UNFCCC Least De veloped Countries Fund (LDCF)

UNFCCC Special Climate Change Fund (SCCF)

GEF climate change projects
The Fund promotes the paradigm shift towards low-emission and climate-resilient development pathways by providing support to developing countries to limit or reduce their greenhouse gas emissions and to adapt to the impacts of climate change. GCF can fund the preparation or strengthening of low emission national development strategies or plans. The Fund supports specific sectors that deliver a substantial impact on mitigation and adaptation, plus cross-cutting priorities as entry points for investment that can have an impact in multiple results areas, targeting both mitigation and adaptation in an integrated and holistic manner.

The GCF may expedite its support for adaptation by seeking synergies between the country programmes and strategic frameworks, providing expedited finance to countries in order to advance their respective processes, as well as signalling to such entities the possibility of developing project and programmes aimed at implementing adaptation actions.

The LDCF focuses on core sectors that link adaptation and development such as water, agriculture and food security, health, disaster risk management and prevention, infrastructure, and fragile ecosystems.

There is currently no explicit opportunity in the criteria for the LDCF to support INDC/NDC related adaptation projects in the LDCs. However, as part of the follow up on the implementation of the LDC work Programme, GEF is encouraged to seek ways to strengthen collaboration with the GCF through the National Adaptation Program of Action to channel resources that would enable LDCs to finance the remaining projects under the national plans.

The SCCF finance projects relating to adaptation, technology transfer and capacity building, energy, transport, industry, agriculture, forestry, waste management, and economic diversification. Among these, adaptation has the top priority. The eligibility criteria and policies for projects and programs financed under the SCCF require that all projects and programs should be consistent with relevant national reports, strategies, policies, plans and legislation. As with the LDCF, there is thus no explicit reporting requirement on $M \& A$ synergies beyond what would be possible through better alignment of eligible criteria.

GEF Climate Change Projects focus on integrated approaches that account for the needs and interconnections between the many environmental dimensions at the local, regional and global levels. Mitigation actions involve direct reduction of GHG emissions through, for example, the scaling up of integrated urban management, sustainable transport, renewable energy and energy efficiency. But effective mitigation also includes reducing emissions from other sectors, such as land use and forestry, and protecting carbon sinks such as the oceans. This includes support for UNFCCC-related reporting and assessments, including (I)NDCs, and to help integrate their findings into national policy planning and implementation.

The GEF harnesses synergies between trust funds, GEF focal areas and multi-lateral environmental agreements. GEF's Cross-Cutting Capacity Development Strategy (2014-2018) aims at catalyzing synergies and emphasizes integration of environmental sustainability across key development sectors. 
Table 24: Overview of green financing criteria (continued)

Climate Investment Funds: Clean Technology Fund (CTF); and Special Climate Fund (SCF)

Nordic Development Fund (NDF)

Nordic Climate Facility (NCF)
The CTF empowers transformation in middle income and developing countries by providing resources to scale up the demonstration, deployment, and transfer of low carbon technologies with a significant potential for long-term greenhouse gas emissions savings. The majority of CTF funding is addressing clean technologies such as renewable energy, energy efficiency, and clean transport. The SCF provides support for three targeted programs with dedicated funding to pilot new approaches with potential for scaled-up, transformational action aimed at a specific climate change challenge or sectoral response.

CIF works to disseminate knowledge being built within the thematic area of climate change, across the programmes, which as the potential to include synergies between mitigation and adaptation in its agenda. PPCR has inter alia collected a 'top 10 Key Lessons' from the PPCR highlighting critical and strategic aspects that need to be considered in resilience planning and implementation in sectors such as agriculture and landscapes, water resources, coastal zone, urban development, climate information systems, and other infrastructure sectors. The PPCR SubCommittee requests MDBs and new pilot countries to design SPCRs to attract funding from other sources, including the GCF, in addition to any resources that may become available in the PPCR. The Sub-Committee also encourages further collaboration between PPCR pilot countries, MDBs, the GCF and the CIF Administrative Unit on the development of SPCRs to facilitate compatibility with GCF's future investment criteria.

NDF's objective is to provide financing and knowledge for climate change adaptation and mitigation and development activities primarily in low-income countries (LIC) in Africa, Asia and Latin America, in line with the Nordic countries' priorities in the area. The NDF applies a specific screening methodology to assess the climate change content of projects ex-ante. Core project criteria on Adaptation projects require that projects should be primarily climate-related, with at least $50 \%$ of total project investment costs incurred due to measures helping to adapt and build resilience to the current or expected impacts of climate change. The parallel criteria for mitigation projects are that projects should have a significant climate component, such as global benefits of GHG emission reduction or carbon sequestration of at least $10 \%$ of project investment costs.

The main objectives of the NCF are to (i) facilitate the exchange of technology, knowledge, know-how and innovative ideas between the Nordic countries and low-income countries in the field of climate change, (ii) to increase the low-income countries' capacity to mitigate and adapt to climate change; and (iii) to contribute to sustainable development and the reduction of poverty. Furthermore, the NCF's objective is also to encourage testing of concrete concepts relating to climate change and to facilitate partnerships. The NCF finances projects that are both climate and development projects. The projects should have a potential to promote technological innovation in areas susceptible to climate change such as: energy, transport, water and sanitation, health, agriculture, and forestry and other areas related to natural resource management, and through calls for proposals focusing on adaptation to and/or mitigation of climate change. NCF has further analysed its portfolio and concluded inter alia that the traditional distinction between mitigation and adaptation fails to depict the variety of linkages between mitigation and adaptation and may lead to underutilized opportunities for synergies, and that also private sector funding needs to be more facilitated in this direction of promoting synergies.

In terms of the GEF and the GEF-administered climate change funds, GEF receives guidance from the COP. Key areas of COP19 guidance involve support for the preparations for (I)NDCSs. Traditionally, GEF climate strategies have focused mainly on sectoral and technology-specific interventions. However, the GEF-6 Programming direction recognized that given the growing significance of climate change influence on all areas of GEF interventions, the GEF-6 Climate Change Mitigation Strategy should also seek to enhance synergies across focal areas, with the aim of generating additional global environmental benefits beyond the original GEF interventions. ${ }^{13}$ 
The programming direction points to the importance of recognizing climate change implications in all GEF focal areas and to addressing both mitigation and climate resilience measures in integrated approaches. Synergies between climate change and other GEF focal areas (and between M\&A) partly derives directly from the environmental conventions themselves, as the conventions highlight the linkages that exist between their respective objectives and recommend actions to promote complementarity and synergy in seeking multiple environmental benefits. GEF seek to promote integration of resilience into all GEF projects, and supports potential co-benefits with other focal areas. In addition, it also pursues specific pilot projects on integrated approaches. ${ }^{14}$

At $\mathrm{COP}_{21}$, the GEF was requested to consider how to support developing countries in formulating policies, strategies, and projects to implement activities that advance priorities identified in their intended nationally determined contributions ((I)NDCs). As part of its response, the GEF is encouraging governments to align the GEF programming for GEF-6 with INDC priorities and cite the relationship with relevant (I)NDCs in their funding proposal submissions.

The GEF has made resources available for countries to prepare their (I)NDCs, and has provided support towards INDC preparations for 46 countries. The GEF also provided technical assistance on (I)NDCs through the Global Support Programme to all countries. The COP has welcomed the GEF approval to support the INDC preparations, and has encouraged the GEF to continue such support. It is still to be seen how this will be implemented in practice, and whether M\&A synergies will receive more attention.

All Nordic countries focus on mitigation and adaptation. However, the Nordic instruments display varying degrees of focus on mitigation and adaptation respectively, as well as on potential synergies and co-benefits.

For example, the Danish NEC-strategy (Natural Resources, Energy and Climate Change Strategy, 2013) mentions mitigation and adaptation as focus areas, but does not further elaborate on the potential for synergies. Norway is focusing on climate change and access to clean energy, particularly through Norway's International Climate and Forestry Initiative (NICFI). The NICFI focuses on thematic areas such as Securing Indigenous and Other Forest-dependent Populations' Rights and Interests, Deforestation-free Commodity Supply Chains and Green Growth, Improved Transparency, Governance and Legality, and Promoting International Consensus on REDD+.

The Nordic Climate Facility (NCF) is financed by the Nordic Development Fund and administered by the Nordic Environment Finance Corporation (NEFCO). The NCF has since its launch in 2009 financed projects balanced within three categories: Adaptation, mitigation and a combination of the two. The NCF launches calls for innovative project concepts each with a specific theme, and has to date carried out six calls for proposals.

A recent study based on a qualitative assessments of selected NCF projects shows how adaptation projects may have business linkages combined with mitigation activi-

${ }_{14}$ Chizuru Aoki: Supporting Synergy, experiences from the GEF Financial Mechanism, Presentation held at COP22, November 2016 at Nordic Finance Day. 
ties, and that public funding can be used to leverage private sector funding for adaptation especially when combined with mitigation efforts. ${ }^{15}$ Several examples from the NCF shows that NCF projects classified as "mitigation only" projects also have adaptation co-benefits. Other "adaptation only" projects (e.g. on watershed management addressing land degradation) have mitigation impacts, such as via sequestration. However, mitigation impacts are not being monitored.

The experiences from NCF also points to that the private sector should not only be seen as source of funding, but as a key actor. The traditional distinction typically used between mitigation and adaptation fails to depict the variety of linkages between mitigation and adaptation. It may be that the mitigation impacts are easier to conceptualize and monitor than the adaptation impacts. Ultimately, the lessons learned from the NCF study shows that it has been easier to attract co-financing from the private sector for NCF projects that had the dual objective of mitigation and adaptation, than attracting co-financing for "adaptation only" projects. The private sector co-financing of the Nordic Climate Facility combination projects (adaptation and mitigation) were presented as part of the Nordic Finance Day at COP22. ${ }^{16}$

Other stakeholders presenting at the same event, particularly from the Latin America and Caribbean (LAC) Region, draw attention to private sector participation in climate finance for adaptation and mitigation synergies in LAC was still very low. Existing international frameworks need to promote a window for integration of mitigation and adaptation, and regional platforms can foster and facilitate proposals that integrate mitigation and adaptation. ${ }^{17}$

\subsection{Summary}

Ultimately, much can be obtained at the operational level with a targeted project and programme preparation framework that appropriately ensures mitigation and adaptation synergies, with monitoring and evaluation documentation activities that focus on synergy aspects. This could be reinforced through integration of synergy approaches into existing result based management frameworks.

In parallel with this, it is important for existing climate funds and donors to support and promote synergies at the national level in developing countries. It is equally important to support further development of synergies between mitigation and adaptation into national development frameworks, action plans at various levels of government, sector-specific action plans, and into the specific project development activities.

\footnotetext{
15 Mobilizing private sector funds for climate adaptation: Nordic Climate Change Facility (NCF) as a case study, K. Haemekoski, H. Sinko.

${ }^{16} \mathrm{Hands}$-on experiences of private/public project financing with Mitigation and Adaptation Synergies, COP22 side Event, 17 (November 2016), Helle Lindegaard, Nordic Finance Cooperation.

${ }^{17}$ Gutiérrez, M.J: Advances in integrating adaptation ad mitigation climate policies in Latin America: key considerations, (November 2016), Presentation held at COP22 side event at the Nordic Finance Day.
} 
Ideally, in the longer term, the synergy aspects could be mainstreamed across the funds where it is not implicit in the funding criteria today. Climate funds may also consider issuing of more specific guidance on how to address synergy aspects between mitigation and adaptation in terms of both content and processes. These opportunities for improvement are outlined in Chapter 7. 



\section{Exploring the feasibility for international climate finance supporting mitigation and adaptation synergies: Discussion and recommendations}

\subsection{Conclusions}

\subsubsection{Looking for four types of synergies: mostly side-effects found}

Climate funds addressing M\&A synergies in the (I)NDCs can contribute to enhancing climate ambition in the implementation of the Paris Agreement. This study applies the definitions of adaptation and mitigation synergies as found in the Annual Reports from the IPCC. Furthermore, we distinguished between four types of inter-relationships between mitigation and adaptation:

- Adaptation actions that affect mitigation actions $(A \rightarrow M)$

- Mitigation actions that affect adaptation actions $(M \rightarrow A)$.

- Decisions that include trade-offs or synergies between adaptation and mitigation $((\mathrm{M}, \mathrm{A}))$.

- Processes that have consequences for both adaptation and mitigation $(\mathrm{A} \cap \mathrm{M}){ }^{18}$

A broad scope has been applied which includes all the inter-relationships categorised as synergies between mitigation and adaptation to avoid limiting the number of examples.

The most frequent type of inter-relationships are those where adaptation actions affect mitigation actions $(\mathrm{A} \rightarrow \mathrm{M}$ ) or where mitigation actions affect adaptation actions $(M \rightarrow A)$, both of which involves side-effects. In rarer instances, those where processes that have consequences for both adaptation and mitigation ( $A \cap M)$ were found. Rarely, pure synergies are identified. These are clear decisions that include trade-offs or synergies between adaptation and mitigation $\left(\int(M, A)\right)$. Relevant examples of synergies were found in a limited number of NDCs:

\footnotetext{
${ }^{18} \mathrm{http}: / /$ climatepolicyinfohub.eu/mitigation-co-benefits-and-interlinkages-adaptation
} 
- The Burkina Faso INDC incorporates actions across most of the sectors analysed, and integrates all types of synergies except from trade-offs or synergies between adaptation and mitigation $\left(\int(\mathrm{M}, \mathrm{A})\right.$.

- The Costa Rican NDC is included as it raises synergies in relation to an ecosystems based approach in agriculture with a potential of benefiting other goals.

- The Tongan NDC is an Island State and represents the specific challenges island countries faces. Tonga has proposed adaptive actions in agriculture and forestry to create climate resilience.

- The Laotian NDC suggests sustainable forest management, while also pointing to hydropower as an action that provides clean energy while meeting other objectives such as flood, irrigation, and water supply. It is also part of the rural electrification programme, which aims at rural development and poverty reduction.

In other words, actions across NDCs do not seem to be designed with a specific aim to promote synergies or bridge trade-offs. Instead, actions described have one of the two targets in mind, and the latter becomes a side-effect (or co-benefit) of the former ( $A \rightarrow$ $\mathrm{M}$ or $\mathrm{M} \rightarrow \mathrm{A}$ ). For example, Belize provides no specific mitigation and adaptation synergies, but states that "the INDC intends to utilize existing frameworks and policies that provide mitigation and sustainable development co-benefits."

\subsubsection{An adaptation-mitigation disconnect}

In general, the analysis shows that a mitigation-adaptation disconnect remains. Thornton and Comberti (2013) define these as situations where "proactive mitigation policies at one level fail to connect or synergise with adaptation processes at another, and may even work at cross-purposes to planned or autonomous processes of adaptation that are working at other levels and scales."

As a strong body of literature shows, there are added benefits when mitigation and adaptation are considered jointly $\left(\int(M, A)\right)$ rather than as an afterthought $(M \rightarrow A$ and $A$ $\rightarrow M) .{ }^{19}$ Incremental and autonomous adaptation may be insufficient in potentially severe situations, as there is a need to further integrate this in policies.

International finance for adaptation has so far fallen short of needed levels of investment. However, the integration of a mitigation and adaptation nexus might already be happening, though it is not reflected to the same extent in the (I)NDCs. As Leonard et al. (2016) find, an "increasing number of synergistic projects are being implemented on the ground."

However, in that context, policy makers have an important role to play in identifying opportunities for this and putting in place measures to increase synergies and avoid trade-offs. Experience indicates that integrated analyses of mitigation and adaptation objectives and potentials could be included as requirements in financing.

${ }_{19}$ See, for example, Swart and Rees, 2007; Klein et al., 2007; Jarvis et al., 2011; Locatelli et al., 2011; Thornton and Comberti, 2013; Duguma et al., 2014; Leonard et al., 2016. 


\subsubsection{Policy framework: Can the Paris Agreement connect adaptation and mitigation?}

The Paris Agreement presents a mixed picture in terms of its link to driving synergies between adaptation and mitigation. The overall policy framework for climate action by parties to the UNFCCC is the Paris Agreement and its decision. While the text that came out of Paris in December 2015 often mentions adaptation and mitigation side by side, it does not explicitly promote synergies. As such is does not call for connecting adaptation and mitigation, though it recognises that consequences of one type of action is possible on the other.

It does, however, set out in the preamble how preventing adverse impacts, enhancing climate resilience, fostering low GHG development and securing food production goes hand in hand. This sets the stage for a cross-sectoral, multidimensional policy and planning process that places not least agriculture in the spotlight.

A majority of parties to the convention still have economies dependent on agriculture and continue to struggle to secure food for growing populations. The question is whether the coming year's technical negotiations under the A-PA, SBSTA, SBI and other technical bodies will see more concrete, synergy-specific elements put into the modalities on the transparency frameworks, technology transfer, or voluntary cooperation.

This could potentially open a gateway for synergistic thinking. An overall reading of the PA and its decision suggests that it does not prevent synergies, but at the same time it does not promote it. Mainstreaming of synergies could have been much better integrated in the text of the agreement. Negotiators have been aware of synergies while drafting the text, but perhaps did not have the knowledge, examples, or tools that could support development of mechanisms or modalities to drive synergies forward. Outcomes in terms of synergies will be determined by how the Agreement and the NDCs will be implemented in practice at national levels. Synergistic implementation of adaptation and mitigation by national governments and promotion of sufficient coherence between M \& $A$ at all levels of planning and implementation is needed.

\subsubsection{Weak link between climate funding and synergies}

Taking note of the shortcomings of the Paris Agreement in terms of coherence between mitigation and adaptation, it becomes even more important to address how international climate funds provide incentives for promoting mitigation and adaptation synergies. The examination of the current funding criteria has shown little gearing towards promotion of the M\&A synergies overall, with few exceptions. Steps are being taken at a strategic level focusing on the promotion of synergies and co-benefits and recognizing the need for addressing potential trade-offs. However, this has not necessarily materialised into specific eligibility or funding criteria for promotion of synergies, nor has it been integrated into the funds' application schemes, programmatic framework, monitoring and reporting requirements, or performance frameworks.

There is thus unharvested potential for strengthening the focus on M\&A synergies at all levels of the funds programme and project cycles. Despite the intention and willingness by climate funds to support (I)NDCs in this regard, synergies will need to be 
operationalized in more explicit terms how this potentially can be done in programme and specific project level design.

\subsection{Recommendations: How to promote synergies in the future?}

In the long term, synergy aspects should be better mainstreamed into the funds where this is not already inherent in the funding criteria today. This study's findings on (I)NDC synergies across sectors indicates that there is a potential to scale up synergistic approaches and to mainstream more synergy into many parties' climate policies.

A potential conceptualization of how to support more synergies is depicted in Figure 4 below. It builds from the assumption that action must be defined bottom-up at national level, particularly in developing countries.

A conclusion from the review of synergies in (I)NDCs suggests that challenges exist in transferring the opportunities to exploit synergies as well as lessons learned with respect to synergies to the national and subnational/regional policy levels in developing countries.

This suggests that available finance and the international policy framework developed through the Paris Agreement must be inductive to be able to realise the potential synergies. This requires the framework to respond to the situations at the national level rather than trying to apply a uniform, pre-established structure across all countries.

If finance is made available to promote synergies and if the policy framework support or even better require synergistic thinking, it is more likely that national policies would integrate synergistic thinking. 
Figure 4: Realising synergies in the (I)NDC - A top-down and Bottom-up approach

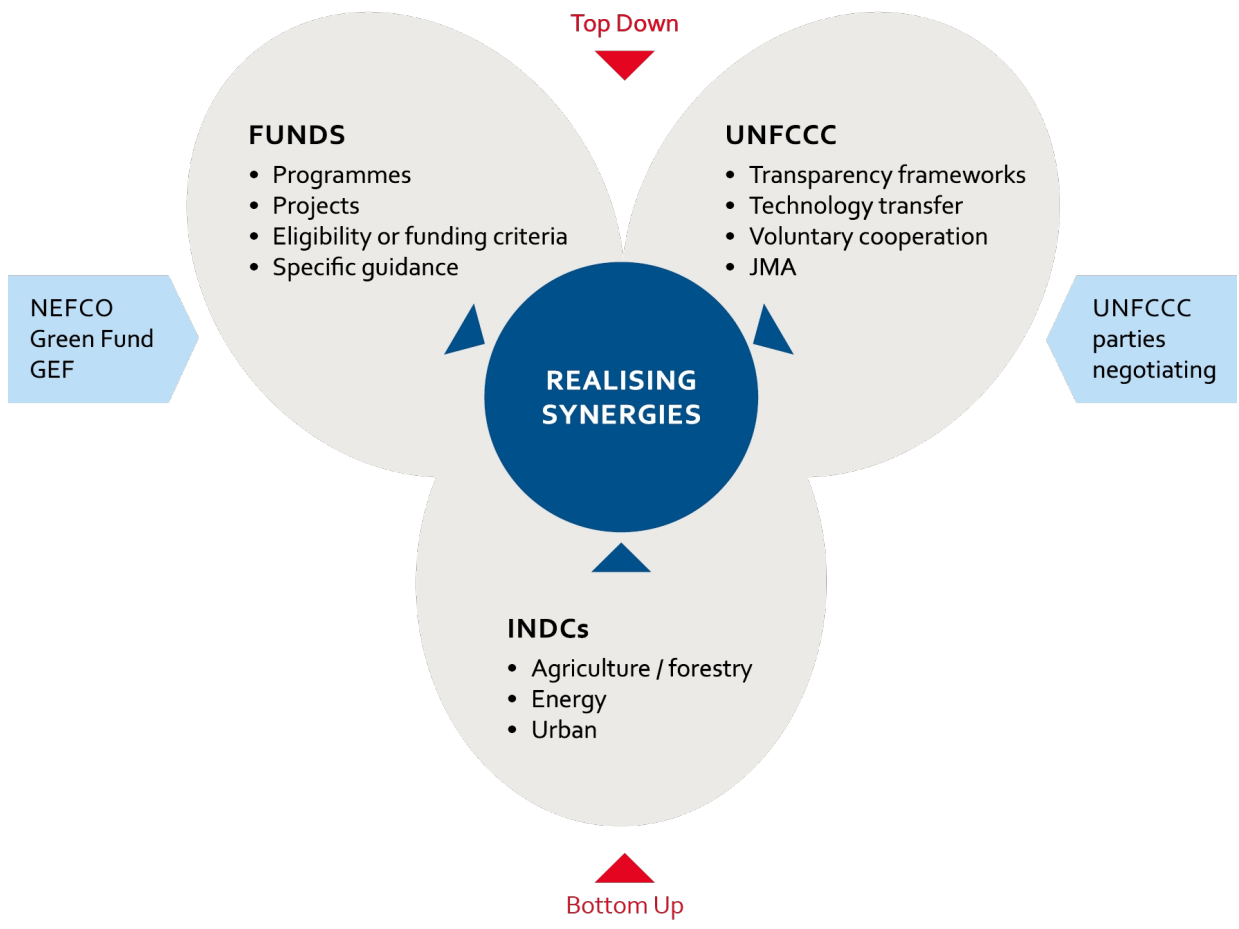

In line with the above concept, three types of opportunities for improvement have been developed. The first area concerns how NDCs are set up representing the party action. The next set focuses on the policy framework, followed by opportunities for improvement concerning financing arrangements.

\subsubsection{Overall policy making recommendations for NDCs}

Although mitigation and adaptation synergies have gained some international policy attention and features in the Paris Agreement, this analysis shows that challenges exist in transferring these experiences and lessons learned to national and subnational policy levels, where many policies with relevance to mitigation and adaptation are designed.

Experience with integrated planning at local levels suggests that shifts in the structure of financing arrangements can have a significant impact on synergies beyond changes in volume..$^{20}$ That is, there are significant variations in synergy depending on delivery mechanisms for financing. Specific tools can be used to incentivise synergy and drive good practices from one programme recipient to another. Such tools include platforms or financing windows that couple financing from multiple sources into larger, targeted instruments that allow for better linkages to be created between mitigation and adaptation.

${ }^{20}$ See, for example, Steve Winkelman: Green Resilience:Adaptation +Mitigation Synergies, webinar presentation held under the Climate Technology Centre \& Network (CTCN), 21st December, 2016. 
These integrated funding platforms could allow for ongoing streams of financing rather than "one off" project-based resources. This allows larger, more ambitious projects to be targeted towards cross-cutting goals. Reinforcing this, applicants to this integrated financial platform could be compelled to identify synergy objectives within project applications that arise from national contexts rather than applying a top-down requirement on the funding partners.

It has been found to be difficult in practice to connect adaptation and mitigation action in the lion's share of NDCs. Drawing on the literature and lessons learned from existing synergies, a number of lessons for further integration of mitigation and adaptation synergies at the national and subnational level can be drawn.

These are relevant for national and subnational governments as well as for international climate funds to consider in the design of concrete climate change projects.

These include:

- Focus on potential adaptation and mitigation benefits when considering an action (i.e. focus on $M \rightarrow A$ and on $A \rightarrow M$ ).

- Consider which parts of a policy that might have consequences for both adaptation and mitigation ( $A \cap M)$.

- Linking adaptation to mitigation and vice versa is an approach, not a target. In other words, seeing synergy as a means not an end.

- Consider synergies at multiple scales (local, regional, national, global) and across sectors (agriculture, forestry, energy, waste, industry, urban).

- Consider potential trade-offs and put in place measures to avoid these.

- Develop institutional links between adaptation and mitigation. Policies should not be developed in independent silos.

- Mainstream adaptation and mitigation considerations into broader development and economic policies.

\subsubsection{Recommendations for ongoing negotiation on the enhanced transparency framework}

The Marrakesh Climate Change Conference (COP22) in November 2016 has been quoted by observers as the "action" COP, meaning the forum in which stakeholders and parties agreed on the action that shall lead to the meeting of the targets enshrined in the Paris Agreement.

The action planned and taken must be reported in the transparency of action system. The Measuring, Reporting, and Verification (MRV) system will gradually substitute the existing system set out in the Kyoto Protocol and its decisions. The nuts and bolts of this system is to be negotiated and agreed in the coming years. In fact, the Paris decision holds a commitment to have this system in place. It is plausible that the Bonn meeting in May 2017 will yield progress, with some groups gathering to start formulating and debating this system. 
In order for this system to support synergies between adaptation and mitigation, parties need to bring this topic to the negotiation room.

- Nordic parties should strive to have synergies included in their negotiation mandates and in the common EU position, and subsequently iterate adaptation and mitigation synergies in Bonn and other events. This may serve to catalyse the discussions across several working groups.

- In the process of defining the "rules, modalities and procedures" for future NDC reporting (Paris Agreement Decision, para 38-39 and 42), where possible, Nordic parties should seek to make it mandatory for submitting parties to include information in future NDCs on how synergy between Adaptation and Mitigation actions has been promoted. This could be in the form of a mandatory information item in NDCs on what actions are considered synergistic and why. This provision could further require that parties classify such synergistic action in accordance with the IPCC terminology applied in this study. While an information item in NDC submission would be forward-looking and stipulate conceptual thinking and planning, a more flexible approach could to require parties to report similar information in their reports under the System for Transparency. This would then entail that a requirement is considered for the "Rules, Modalities and Procedures" to be developed following from para 95 of the decision.

- Nordic parties should seek further refinement of the initiatives by taking into consideration a specific synergy task force, perhaps even allocating funding to synergy support for developing country parties. This third approach builds on the capacity building initiative foreseen under paras $85-86$ of the decision.

- Parties should add a requirement for a dedicated synergies session under the Global Stocktake. In practice, this means that it is recommended that in the work of the parties under para 102 of the Decision, when drafting modalities, a mandatory synergies session should be ensured. An added benefit of this recommendation is that synergies between adaptation and mitigation would be promoted and highlighted at a high level.

\subsubsection{Recommendations for realising synergies through international climate finance}

There is room for improvements in the way that current climate funds address synergies between mitigation and adaptation. Where potential synergies may be emphasized as important at strategic level (GCF, GEF), this has not necessarily materialized into the specific fund investment criteria or at project level. When not requested as an explicit criteria or an explicit reporting obligation, consequently the opportunity for receiving monitoring and reporting information on synergies is also missed.

Identifying and integrating the relevant climate change aspects at all levels of the project and programme cycle will help generate relevant M\&A synergies. In the short 
term, much can be obtained at the operational level with a targeted project and programme preparation framework that appropriately ensures M\&A synergies, with monitoring and evaluation documentation activities that also include focus on synergy aspects, and through integration of synergy approaches into existing results-based management frameworks.

Financing as an economic policy instruments could be combined with a purpose of informational function, as a requirement of integrated mitigation and adaptation analyses could serve to raise awareness and knowledge about potential synergies. To further this, reporting requirements could stipulate a format for the presentation of such analyses, to facilitate more effective lessons transfer.

Climate funds may also consider issuing specific guidance on how to address synergies between $M \& A$ in terms of both content and processes supporting developing countries in mainstreaming this into their national development frameworks, climate strategies and action plans at the various governmental levels and into sector specific action plans and the specific programme and project development activities.

Generally, there is no explicit requirements for information on this issue in the climate funds primarily addressing mitigation. Often, reference is only made to extent that the project is in consistency with the relevant national climate change mitigation and adaptation strategy/action plan without being specific about the adaptation or vulnerability dimension.

Moreover, climate funds could benefit from introducing or strengthening the information requirements on identifying trade-off aspects by explicitly requesting such information from applicants and grantees, and by explicitly addressing this in programming frameworks and design.

Core indicators could be developed to support such promotion and would ease the reporting across Funds on co-financed projects. This would include identifying specific action areas in which progress needs to be made, and designing a set of indicators that take annual measures of progress in specific areas. 


\section{References}

Aoki Chikuru, (November 2016): Supporting Synergy, experiences from the GEF Financial Mechanism, Presentation held at COP22 at the Nordic Finance Day.

Bruckner T., I. A. Bashmakov, Y. Mulugetta, H. Chum, A. de la Vega Navarro, J. Edmonds, A. Faaij, B. Fungtammasan, A. Garg, E. Hertwich, D. Honnery, D. Infield, M. Kainuma, S. Khennas, S. Kim, H. B. Nimir, K. Riahi, N. Strachan, R. Wiser, and X. Zhang (2014). Energy Systems. In: Climate Change 2014: Mitigation of Climate Change. Contribution of Working Group III to the Fifth Assessment Report of the Intergovernmental Panel on Climate Change [Edenhofer, O., R. Pichs-Madruga, Y. Sokona, E. Farahani, S. Kadner, K. Seyboth, A. Adler, I. Baum, S. Brunner, P. Eickemeier, B. Kriemann, J. Savolainen, S. Schlömer, C. von Stechow, T. Zwickel and J.C. Minx (eds.)]. Cambridge University Press, Cambridge, United Kingdom and New York, NY, USA. (Available from https://www.ipcc.ch/pdf/assessment-report/ar5/wg3/ ipcc_wg3_ar5_chapter7.pdf).

Cavers, S., J.E. Cottrell (2015). The basis of resilience in forest tree species and its use in adaptive forest management in Britain. Forestry 88: 13-26. https://doi.org/10.1093/forestry/cpu027

CAIT (2017). Climate data explorer. Paris contributions map. (Available from http://cait.wri.org/ indc/).

Copeland, C. (2014). Energy-water nexus: the water sector's energy use. Congressional Research Service. January, 3. (Available from https://www.fas.org/sgp/crs/misc/R43200.pdf).

Duguma, L. A., Minang, P. A., M. van Noordwijk (2014). Climate change mitigation and adaptation in the land use sector: from complementarity to synergy. Environmental management, 54, 420-432. https://doi.org/10.1007/s00267-014-0331-x

Easterling, W.E., P.K. Aggarwal, P. Batima, K.M. Brander, L. Erda, S.M. Howden, A. Kirilenko, J. Morton, J.F. Soussana, J. Schmidhuber, F.N Tubiello (2007). Food, fibre and forest products. In: Parry ML, Canziani OF, Palutikof JP, van der Linden PJ, Hanson CE, eds. Climate change 2007: Impacts, adaptation and vulnerability. Contribution of Working Group II to the Fourth Assessment Report of the Intergovernmental Panel on Climate Change. Cambridge, UK: Cambridge University Press. pp. 273-313. (Available from https://www.ipcc.ch/pdf/ assessment-report/ar4/wg2/ar4-wg2-chapter5.pdf).

Northrop E., H. Biru, S. Lima, M. Bouye and R. Song (September 2016). Examining the Alignment between the Intended Nationally Determined Contributions and Sustainable Development Goals. Working Paper. Washington, DC: World Resource Institute.

European Environment Agency (2009). Water Resources Across Europe: Confronting Water Scarcity and Drought. http://www.eea.europa.eu/

FAO (2006). Livestock's Long Shadow: environmental issues and options. Available from http://www.fao.org/docrep/010/a0701e/ao701eoo.HTM

FAO (2013). Climate-smart agriculture sourcebook. Rome, Italy: Food and Agriculture Organization of the United Nations. (Available from http://www.fao.org/docrep/018/i3325e/ i3325e.pdf.).

FAO (2011). Potential effects of climate change on crop pollination. Rome, Italy: Food and Agriculture Organization of the United Nations. (Available from http://www.fao.org/ fileadmin/templates/agphome/documents/Biodiversity-pollination/ Climate_Pollination_17_web__2_.pdf).

Gutiérrez, M.J. (November, 2016) Advances in integrating adaptation and mitigation climate policies in Latin America: key considerations. Presentation held at COP 22 side event at the Nordic Finance Day. 
Harvey, C. A., M. Chacón, C. I. Donatti, E. Garen, L. Hannah, A. Andrade, et al. (2014). ClimateSmart Landscapes: Opportunities and Challenges for Integrating Adaptation and Mitigation in Tropical Agriculture. Conservation Letters, 7, 77-90. https://doi.org/10.1111/conl.12066

Hoff, H. (2011). Understanding the Nexus. Background Paper for the Bonn 2011 Conference: The Water, Energy and Food Security Nexus. Stockholm Environment Institute, Stockholm, Sweden.

Illman, J., M. Halonen, P. Rinne, S. Huq, S. Tveitdal (2013). Scoping study on financing adaptation-mitigation synergy activities. Nordic Council of Ministers, Nordic working papers. (Available from http://dx.doi.org/10.6027/NA2013-902).

ICRAF (2016). Agroforestry and our role. (Available from: http://www.worldagroforestry.org/ about/agroforestry-our-role).

IPCC (2015). Adaptation and mitigation. (Available from http://ar5-syr.ipcc.ch/ topic_adaptation.php).

IPCC (2014). Annex II: Glossary. Mach, K.J., S. Planton and C. von Stechow (eds.). In: Climate Change 2014: Synthesis Report. Contribution of Working Groups I, II and III to the Fifth Assessment Report of the Intergovernmental Panel on Climate Change. Core Writing Team, R.K. Pachauri and L.A. Meyer (eds.). IPCC, Geneva, Switzerland. (Available from https://www.ipcc.ch/pdf/assessment-report/ar5/syr/AR5_SYR_FINAL_Glossary.pdf).

Jarvis, A., C. Lau, S. Cook, E. Wollenberg, J. Hansen, O. Bonilla, A. Challinor (2011). An integrated adaptation and mitigation framework for developing agricultural research: synergies and tradeoffs. Experimental Agriculture 47:185-203. https://doi.org/10.1017/So014479711000123

Junghans, L., S. Harmeling, M. Köhler, M. Boos, S. Butzengeiger, A. Michaelowa (2013). Advancing climate compatible development for food security: Task 3 - Assessment how food security-related elements of national climate change strategies can harness international climate finance in an effective manner. Hamburg, Boon, 18th of February 2013. (Available from https://germanwatch.org/en/download/8345.pdf).

Klein, R.J.T., S. Huq, F. Denton, T.E. Downing, R.G. Richels, J.B. Robinson, F.L. Toth (2007). Inter-relationships between adaptation and mitigation. Climate Change 2007: Impacts, Adaptation and Vulnerability. Contribution of Working Group II to the Fourth Assessment Report of the Intergovernmental Panel on Climate Change, M.L. Parry, O.F. Canziani, J.P. Palutikof, P.J. van der Linden and C.E. Hanson, Eds., Cambridge University Press, Cambridge, UK, 745-777. (Available from https://www.ipcc.ch/pdf/assessment-report/ar4/wg2/ar4-wg2-chapter18.pdf).

Lasco, R.D., R.J.P. Delfino, M.L.O. Espaldon (2014). Agroforestry systems: helping smallholders adapt to climate risks while mitigating climate change. Wiley Interdisciplinary Reviews: Climate Change 5, 825-833. https://doi.org/10.1002/wcc.301

Legrève, A., Duveille, E. (2010). Preventing potential disease and pest epidemics under a changing climate. In: Reynolds MP, ed. Climate change and crop production. Wallingford, UK: CABI Publishing. https://doi.org/10.1079/9781845936334.0050

Leonard, S., B. Locatelli, D. Murdiyarso, C. Martius, M. Quina, H. Baral (2016). A match made in Paris: Adaptation-mitigation synergies in the land sector, CIFOR InfoBrief, Vol. 137. (Available from http://www.cifor.org/publications/pdf_files/infobrief/6106-infobrief.pdf).

Levine, M., D. Ürge-Vorsatz, K. Blok, L. Geng, D. Harvey, S. Lang, G. Levermore, A. Mongameli Mehlwana, S. Mirasgedis, A. Novikova, J. Rilling, H. Yoshino, 2007: Residential and commercial buildings. In Climate Change 2007: Mitigation. Contribution of Working Group III to the Fourth Assessment Report of the Intergovernmental Panel on Climate Change [B. Metz, O.R. Davidson, P.R. Bosch, R. Dave, L.A. Meyer (eds)], Cambridge University Press, Cambridge, United Kingdom and New York, NY, USA. (Available from https://www.ipcc.ch/ pdf/assessment-report/ar4/wg3/ar4-wg3-chapter6.pdf).

Lindegaard, H., 2016: Hands-on experiences of private/public project financing with Mitigation and Adaptation Synergies, COP22 side Event, 17 November 2016, Nordic Finance Cooperation.

Locatelli, B., V. Evans, A. Wardell, A. Andrade, R. Vignola (2011). Forests and climate change in Latin America: Linking adaptation and mitigation, Forests 2, 431-50.

https://doi.org/10.339o/f2010431 
Locatelli, B., M. Kanninen, M. Brockhaus, C.J.P. Colfer, D. Murdiyarso, H. Santoso (2008). Facing an uncertain future: How forests and people can adapt to climate change. Forest Perspectives no. 5. Bogor, Indonesia: Center for International Forestry Research. (Available from http://www.cifor.org/publications/pdf_files/media/CIFOR_adaptation.pdf).

Lucon O., D. Ürge-Vorsatz, A. Zain Ahmed, H. Akbari, P. Bertoldi, L. F. Cabeza, N. Eyre, A. Gadgil, L. D. D. Harvey, Y. Jiang, E. Liphoto, S. Mirasgedis, S. Murakami, J. Parikh, C. Pyke, and M. V. Vilariño, 2014: Buildings. In: Climate Change 2014: Mitigation of Climate Change. Contribution of Working Group III to the Fifth Assessment Report of the Intergovernmental Panel on Climate Change [Edenhofer, O., R. Pichs-Madruga, Y. Sokona, E. Farahani, S. Kadner, K. Seyboth, A. Adler, I. Baum, S. Brunner, P. Eickemeier, B. Kriemann, J. Savolainen, S. Schlömer, C. von Stechow, T. Zwickel and J.C. Minx (eds.)]. Cambridge University Press, Cambridge, United Kingdom and New York, NY, USA. (Available from https://www.ipcc.ch/ pdf/assessment-report/ar5/wg3/ipcc_wg3_ar5_chapterg.pdf).

Richards, M., T.B. Bruun, B. Campbell, L.E. Gregersen, S. Huyer, V. Kuntze, et al. (2015). How countries plan to address agricultural adaptation and mitigation. Info note. (Available from https://cgspace.cgiar.org/rest/bitstreams/63683/retrieve).

Richards, M., O.B. Sander (2014). Alternative wetting and drying in irrigated rice. Implementation guide for policymakers and investors. Practice Brief: Climate smart agriculture. (Available from https://cgspace.cgiar.org/rest/bitstreams/34363/retrieve).

Rizvi, A.R., S. Baig, E. Barrow, C. Kumar (2015). Synergies between Climate Mitigation and Adaptation in Forest Landscape Restoration. Gland, Switzerland: IUCN. (Available from https://portals.iucn.org/library/sites/library/files/documents/2015-013.pdf).

Rodriguez, D.J., A. Delgado, P. DeLaquil, A. Sohns (2013). Thirst Energy. World Bank, Washington DC, USA.

Seto K. C., S. Dhakal, A. Bigio, H. Blanco, G. C. Delgado, D. Dewar, L. Huang, A. Inaba, A. Kansal, S. Lwasa, J. E. McMahon, D. B. Müller, J. Murakami, H. Nagendra, and A. Ramaswami, 2014: Human Settlements, Infrastructure and Spatial Planning. In: Climate Change 2014: Mitigation of Climate Change. Contribution of Working Group III to the Fifth Assessment Report of the Intergovernmental Panel on Climate Change [Edenhofer, O., R. Pichs-Madruga, Y. Sokona, E. Farahani, S. Kadner, K. Seyboth, A. Adler, I. Baum, S. Brunner, P. Eickemeier, B. Kriemann, J. Savolainen, S. Schlömer, C. von Stechow, T. Zwickel and J.C. Minx (eds.)]. Cambridge University Press, Cambridge, United Kingdom and New York, NY, USA. (Available from https://www.ipcc.ch/pdf/assessment-report/ar5/wg3/ipcc_wg3_ar5_chapter12.pdf).

Smith, P., D. Martino, Z. Cai, D. Gwary, H. Janzen, P. Kumar, B. McCarl, S. Ogle, F. O'Mara, C. Rice, B. Scholes, et al. (2008). Greenhouse gas mitigation in agriculture. Philosophical Transactions of the Royal Society B: Biological Sciences 363, 789-813 (Available from https://doi.org/10.1098/rstb.2007.2184).

Sorensen, P., D. S. Hansen, A.S. Olesen, S. L. Bager, P. Stigson, COWI (2016): Mitigation \& Adaptation Synergies in the INDCs \& Financing Opportunities, Presentation held at COPP 22 Side Event, Nordic Finance Day.

Steinfeld, H., P. Gerber, T. Wassenaar, V. Castel, M. Rosales, C. De Haan, (2006). Livestock's long shadow. Rome, Italy: Food and Agriculture Organization of the United Nations.

Stigson, P., S. Roth, A. Karlsson (2014). Re-evaluating the sustainability of energy systems: the nexus of energy, water and land-use. In: Yan, J. (Ed.), Handbook of Clean Energy Systems 6, 1-14. Wiley.

Swart, R., F. Raes (2007) Making integration of adaptation and mitigation work: mainstreaming into sustainable development policies? Climate Policy 7, 288-303.

https://doi.org/10.1080/14693062.2007.9685657

Thorlakson, T. H. Neufeldt (2012). Reducing subsistence farmers' vulnerability to climate change: evaluating the potential contributions of agroforestry in western Kenya. Agriculture \& Food Security 1, 1-13. https://doi.org/10.1186/2048-7010-1-15

Thornton, P.K., P. Gerber (2010). Climate change and the growth of the livestock sector in developing countries. Mitigation and Adaptation Strategies for Global Change 15,169-184. https://doi.org/10.1007/s11027-009-9210-9 
Thornton, T. F., C. Comberti (2013). Synergies and trade-offs between adaptation, mitigation and development. Climatic Change, Special Issue on "Climate Change Mitigation and Adaptation with Local Communities and Indigenous Peoples", 1-14 (doi:10.1007/s10584-013-0884-3).

Udvardy, S., S. Winkelman (2014). Green resilience: Climate adaptation + mitigation synergies. Center for Clean Air (CCAP). April 2014. (Available from http://ccap.org/assets/

CCAP-Green-Resilience-Climate-Adaptation-Mitigation-Synergies_April-2014.pdf).

UNEP DTU (2016). Joint adaptation and mitigation in agriculture and forestry. UNEP DTU Partnership Working Papers series: Climate Resilient Development Programme, Working Paper 2. (Available from http://www.unepdtu.org/-/media/Sites/Uneprisoe/ Working\%20Papers/Joint-adaptation-and-mitigation_updated_09-08-16.ashx).

UNFCCC 2015 ' Paris Agreement' available online at http://unfccc.int/files/meetings/ paris_nov_2015/application/pdf/paris_agreement_english.pdf

UNGA (United Nations General Assembly). 2015. "Transforming our World: The 2030 Agenda for Sustainable Development." Resolution adopted by the General Assembly on 25 September, 2015 (A/RES/70/1). Available online at: http://www.un.org/ga/search/ view_doc.asp?symbol=A/RES/70/1\&Lang=E

UNFCCC (2017). Paris Agreement - Status of Ratification, 4 January 2017. (Available from http://unfccc.int/paris_agreement/items/9444.php).

Valin, H., D. Peters, D., M. van den Berg, S. Frank, P. Havlik, N. Forsell, et al. (2015). The land use change impact of biofuels consumed in the EU: Quantification of area and greenhouse gas impacts. (Available from https://ec.europa.eu/energy/sites/eniner/files/documents/ Final\%2oReport_GLOBIOM_publication.pdf).

Winkleman, S (2016). CTCN/CCAP Webinar: Green Resilience: Adaptation + Mitigation Synergies. Climate Technology Centre and Network. (Available: https://www.ctc-n.org/ sites/www.ctc-n.org/files/ ctcn_ccap_webinar_green_resilience_adaptation_mitigation_synergies.pdf).

Yadoo, A., H. Cruickshank (2012). The role for low carbon electrification technologies in poverty reduction and climate change strategies: $A$ focus on renewable energy mini-grids with case studies in Nepal, Peru and Kenya. Energy Policy 42, 591-602.

https://doi.org/10.1016/j.enpol.2011.12.029 


\section{Resumé}

Konsekvenserne af klimaforandringerne bliver stadig tydeligere med påvirkning af økosystemer, tab af biodiversitet, ekstremvejr, oversvømmelse og påvirkninger af landbruget til følge. Handling er nødvendig for at afhjælpe virkningerne af klimaændringer og for at undgå at virkninger yderligere forværres. En række løsninger er blevet udviklet til at imødegå klimaændringer, mens andre løsninger skal forsøge at afværge yderligere skade. For nyligt er de politiske beslutningstagere begyndt at identificere løsninger der skaber bedre synergier mellem klimatilpasning og afbødende emissionsreduktioner.

Synergier som defineret i IPPCs fjerde hovedrapport kan forstås som "samspil mellem klimatilpasning og afbødning, så deres samlede effekt er større end summen af deres virkninger, hvis de gennemføres separat."

En sådan synergitilgang nedbryder begrebsmæssigt den traditionelle sondring mellem klimatilpasning og afbødning som to separate domæner og tilskynder en integreret tilgang på forskellige politiske niveauer.

I praksis har den internationale klimafinansiering hidtil været rettet mod enten afbødning eller klimatilpasning. De internationale finansieringsinstrumenter har hidtil ikke stillet udtrykkeligt krav om at fremme relevante synergier mellem afbødning og klimatilpasning (M \& A). Dette gælder både eksisterende og nye klimaaftaler, navnlig Parisaftalen og flere samarbejdsmekanismer hvori de nordiske lande deltager.

Mens Parisaftalen potentialt skaber en ramme for synergi mellem afbødning og klimatilpasning, kan aftalen ikke aftvinge de relevante finansieringsordninger at bevæge sig i den retning. Ikke desto mindre findes der et uudnyttet potentiale for at reorientere den eksisterende internationale finansieringsarkitektur med henblik på at fremme synergier mellem afbødning og klimatilpasning. Dette kan gøres både gennem aktiviteter på det operationelle plan og på programniveau. f.eks. gennem brug af målrettede kvalifikations- og rapporteringskrav, der fremmer synergier. Synergifremme vil således afhænge af de strategier, der forhandles og aftales for det relevante program design.

Denne rapport er resultat af et studie "Mitigation \& Adaptation Synergies in the NDCs", udarbejdet af COWI A/S for Nordisk Arbejdsgruppe for globale klimaforhandlinger (NOAK) under Nordisk Ministerråd. Formålet med studiet er at gennemgå mulige afbødnings- og klimatilpasningssynergier $\mathrm{i}$ de indsendte nationalt bestemte reduktionsbidrag (Nationally Determined Contributions', NDC'er) og at identificere mulige tilgange til synergifremme, og koble disse synergier til internationale klimafinansiering.

Undersøgelsen fokuserer på skovbrug, landbrug, energi og byudvikling, områder hvor de nordiske lande har særlig ekspertise i at integrere og kombinere afbødnings- og klimatilpasningstiltag. 
Rapporten tager udgangspunkt i etableringen af en teoretisk arbejdsmodel for begrebet synergi, der giver et udgangspunkt for den efterfølgende analyse af M \& A synergier. Rapporten skifter herefter fokus til praktisk anvendelse og beskriver dernæst potentielle synergier i udviklingslandenes NDC'er og giver eksempler på synergier i de udvalgte sektorer.

Derefter følger en analyse af elementerne i Parisaftalen, som kan anvendes til at hjælpe støtte M \& A synergier. Selvom Parisaftalen ikke udtrykkeligt kræver M \& A synergier, giver elementer $\mathrm{i}$ aftalen passende rammer for aktører til at fremme synergier gennem implementering. Rapporten gennemgår dernæst de nuværende klimafonde og disses finansieringskriterier med henblik på at vurdere i hvilket omfang disse fremmer M \& A synergier.

Baseret på denne gennemgang kan det konstateres at der er plads til forbedringer i måden hvorpå de nuværende klimamidler søger at fremme synergieffekter mellem afbødning og klimatilpasning. Generelt har finansieringskriterierne ikke fremmet M \& A synergieffekter, med få undtagelser. Fokus har primært været på synergifremme på strategisk niveau. Dette har dog ikke nødvendigvis materialiseret sig i specifikke støttemål eller finansieringskriterier til synergifremme. Tilsvarende er synergikrav ikke blevet integreret i fondenes ansøgningsordninger, programmeringsrammer, eller i krav til monitorering og afrapportering.

Der er således et stort uudnyttet potentiale for at styrke fokus på M \& A synergier på alle niveauer af klimafondenes programmer og projektcyklus. På trods af hensigten om at støtte NDC'erne i denne henseende, vil synergier skulle operationaliseres i både program og projektspecifikt design som en integreret tilgang og ikke kun et mål.

I lyset af fleksibiliteten i de eksisterende klimafinansieringsrammer, bør nordiske interessenter presse på i de igangværende og fremtidige forhandlinger for specifikke tiltag til integration af M \& A synergier på nationalt og subnationalt niveau. Dette kan være tiltag med henblik på at:

- integrere potentielle klimatilpasning og afbødning fordele som et vigtigt nøglekriterium i implementering af nationale strategier og handlingsplaner

- identificere politikker, som fremskynder både tilpasning og afbødning

- fremhæve synergier på samtlige niveauer (lokalt, regionalt, nationalt, globalt) og på tværs af sektorer (landbrug, skovbrug, energi, affald, industri, urban)

- identificere potentielle trade-offs og iværksætte foranstaltninger for at undgå eller afbøde disse

- styrke institutionelt samarbejde mellem klimatilpasning og afbødning for at undgå at politikker udvikles i silotænkning

- integrere klimatilpasnings- og afbødningsovervejelser i den eksisterende udviklingspolitik og økonomiske politikker. 
Mere specifikt bør de nordiske lande arbejde for synergifremme i regi af UNFCCC ved at:

- tilstræbe at synergier skal indgå i den fælles EU-holdning til program design

- foranstalte at parter skal medtage oplysninger i fremtidige NDC'er om hvordan synergier mellem klimatilpasning og afbødning er søgt integreret

- give støtte til en dedikeret Task Force for Synergi, herunder eventuel støtte til udviklingslandene med henblik på synergifremme

- fremme en dedikeret synergisession under Global Stocktake.

Måden hvorpå de nuværende klimamidler kan fremme synergi mellem afbødning og klimatilpasning kan forbedres også i selve klimafinansieringsarkitekturen. Synergier er identificeret og formuleret på strategisk niveau, men har ikke nødvendigvis materialiseret sig i specifikke investeringskriterier eller på projektniveau.

De nordiske aktører bør arbejde for at fremme følgende tiltag i forhandlingerne vedrørende klimafinansiering:

- Identificere og integrere relevante klimaændringsaspekter på alle niveauer af project- og program cyklus til fremme af relevante $M \& A$ synergier.

- Udvikle målrettede projekt- og programforberedende rammer, der sikrer M \& A synergier og indeholder dokumenteret monitorering og evaluering, der rapporterer på de relevante synergiaspekter indenfor de eksisterende, resultatbaserede ledelsesrammer.

- Kombinere finansiering med en oplysning for at øge bevidstheden og viden om potentielle synergier mellem M \& A. Rapporteringskravene kan f.eks. fastsætte et format for præsentation af de udførte synergianalyser for at sikre mere effektiv videnoverførsel.

- Udstede specifikke vejledninger til hvordan synergier mellem M \& A kan styrkes $i$ nationalt udviklingsregi samt $\mathrm{i}$ klimastrategier og handlingsplaner på samtlige administrative niveauer. Dette gælder også sektorspecifikke handlingsplaner og programmer samt projektudviklingsaktiviteter.

- Arbejde for specifikke krav til klimainvesteringsmidler primært rettet afbødning. For afbødningsprojekter der kan påvirke klimatilpasningstiltag er det i dag i vidt omfang op til ansøgere / støttemodtagere hvorvidt klimatilpasning, sårbarhed, og klimamodstandsdygtighed aspekter overhovedet adresseres.

- Styrke krav om oplysninger vedrørende synergi og trade-off aspekter i forhold til afbødning og klimatilpasning ved udtrykkeligt at anmode ansøgere/ støttemodtagere om sådanne oplysninger. 
- Udvikle nøgleindikatorer til at fremme M \& A synergier over tid og i løbet af den politiske proces. 


\title{
Annex A: Current climate funding criteria
}

\section{Table 1: UNFCCC Green Climate Fund (GCF), objective and funding criteria}

\author{
UNFCC Green Climate Fund (GCF)
}

Objective and result

areas

Eligibility and funding

criteria

Application require-

ments

Monitoring and reporting requirements

The Green Climate Fund seeks impact within eight mitigation and adaptation results areas chosen because of their potential to deliver a substantial impact on mitigation and adaptation. These are 4 result areas on mitigation (Energy access and power generation; Low emission transport; Buildings, cities, industries and appliances; Forestry and land use): and 4 on Adaptation (Most vulnerable people and communities; Health and well-being, food and water security; Infrastructure and built environment; Ecosystems and ecosystem services). The GCF focuses further on five cross-cutting investment priorities as entry points for investment that can have an impact in multiple results areas, targeting both mitigation and adaptation in an integrated and holistic manner, and with substantial co-benefits ${ }^{21}$. It is stated in the investment framework that the GCF will actively promote synergies across areas of adaptation and mitigation wherever possible. ${ }^{22}$

As per the GCF Governing Instrument (GI), the GCF strives to maximize the impact of its funding for adaptation and mitigation.

Paragraph 2 of the GI defines the purpose of the fund as follows; "In the context of sustainable development, the Fund will promote the paradigm shift towards low-emission and climateresilient development pathways by providing support to developing countries to limit or reduce their greenhouse gas emissions and to adapt to the impacts of climate change." Paragraph 35 defines that the GCF will finance agreed full and agreed incremental costs for activities to enable and support enhanced action on adaptation, mitigation (including REDDplus), technology development and transfer (including carbon capture and storage), capacity-building and the preparation of national reports by developing countries. The Gl establishes a balance in the allocation of resources between adaptation and mitigation echoed in decision B.06/06 where the GCF Board decided to aim for a 50:50 balance between mitigation and adaptation over time.

The GI provides that the GCF can fund the preparation or strengthening of low emission development strategies or plans, including nationally appropriate mitigation actions, national adaptation programmes of action (NAPAs) and NAPs through its Readiness and Preparatory Support Programme. Currently, there is no explicit reference to promotion of synergies between mitigation and adaptation, or that such synergies should be promoted in the Support of (I)NDCs/NDCs.

Applicants submitting a Concept Note used for programmes/project proposals or a Funding Proposal for a full project may tick off whether proposals are relevant for mitigation or adaptation, or as a third option, cross-cutting. Applicants are asked to report on which of the GCF's eight Result Areas the project will deliver on, and can thus mark all that apply, both M and A. Applicants should also state expected climate mitigation/adaptation impact potential and performance against investment criteria and the fund's performance measurement framework, for mitigation and/or adaptation. Sustainable development potential is referred to merely as economic, social and environmental co-benefits. There is no explicit incentive or reporting requirement on M\&A synergies as such, thus this is left at the discretion of the applicant on a case-by-case basis (described in the User's guide as "significant leeway to respond to quantitative and qualitative factors").

However, in the Performance Measurement Frameworks (PFM), mitigation projects/programmes that also generate adaptation results should report on adaptation indicators (and vice versa for adaptation projects/programmes with mitigation results). As an illustrative example is mentioned a project that primarily intends to improve land and forest areas contributing to emission reductions (result 9.0 in the mitigation PMF) and, by doing so, also contribute to increasing the resilience of the ecosystem (result 4.0 in the adaptation PMF) would report on the relevant indicators for both mitigation and adaptation. 
The GCF Board has recently decided "to expedite support for developing countries for the formulation of national adaptation plans (NAP) consistent with UNFCCC decisions" 23 ... thus also through which M \& A deciding that current GCF modalities enable support for the preparation and implementation of the nationally determined contributions (NDCs) and adaptation-related elements of the synergies may be pro- $\quad$ Paris Agreement.

moted Paris Agreement. 作 countries in order to advance their respective NAP processes, as well as signalling to such entities the possibility of developing project and programmes aimed at implementing adaptation action identified in NAPs, nationally determined contributions and other relevant climate policies.

Promotion of M\&A synergies in relation to the complementarity and coherence of the GCF with other Funds may be promoted through an "established dialogue" at the level of delivery of climate finance, foreseen as part of the GCF operational framework.

\section{Table 2: UNFCCC Least Developed Countries Fund (LDCF), objective and funding criteria}

\section{Least Developed Countries Fund (LDCF)}

Objective The LDCF is the first and most comprehensive adaptation action-focused fund currently in operation for least developed countries (LDCs) and addresses the special needs of the 51 Least Developed Countries (LDCs) that are especially vulnerable to the adverse impacts of climate change.

The LDCF is mandated by the Parties to the UNFCCC to provide support to the LDCs' climate change adaptation efforts, including the preparation of National Adaptation Programmes of Action (NAPAs), the implementation of NAPA priority projects, as well as support for the preparation of the National Adaptation Plan (NAP) process in eligible developing countries. The LDCF focuses on core sectors that link adaptation and development such as water, agriculture and food security, health, disaster risk management and prevention, infrastructure, and fragile ecosystems.

Eligibility and funding The eligibility criteria and policies for projects and programs financed under the LDCF require that all projects and programs should be consistent with the mandate, goal and objectives of the LDCF and be consistent with relevant national reports, strategies, policies, plans and legislation. The LDCF/SCCF Council document: Operationalizing Support to the Preparation of the National Adaptation Plan Process in Response to Guidance from the UNFCCC COP (GEF/LDCF.SCCF.14/06) guides the programming and defines the objectives, principles, scope and modalities for GEF support, through the LDCF and the SCCF, for the preparation of the NAP process in eligible developing countries.

There is currently no explicit opportunity in the criteria for the LDCF to support INDCINDC related adaptation projects in the LDCs.

Application require- There is no explicit requirement for applicants to provide information on M\&A synergies.

ments

Monitoring and reporting

Applicants monitor and report on progress towards adaptation outcomes and impacts mainly in the form of reduced vulnerability and enhanced adaptive capacity. There is thus no explicit reporting requirement on M\&A synergies.

M \& A synergies

Coordination and synergies are sought in line with GEF-6 programming direction. The GEF seeks synergies with the Green Climate Fund (GCF), acknowledging the decision of the COP that through...

a "significant share of new multilateral funding for adaptation should flow through the [GCF]"24 (decision 1/CP.16). Also, as part of the follow up on the implementation of the LDC work

Programme, GEF is encouraged to seek ways to strengthen collaboration with the GCF to channel resources that would enable LDCs to finance the remaining projects under the NAPAs.

${ }^{23} \mathrm{GCF} / \mathrm{B} .13 / 05$, Adaptation planning processes, 17th June 2016 .

${ }_{24}$ GEF programming Strategy on Adaptation to Climate Change Adaptation, October 2014 
Table 3: UNFCCC Special Climate Change Fund (SCCF), objective and funding criteria

Special Climate Change Fund (SCCF)

Objective The SCCF finance projects relating to: adaptation; technology transfer and capacity building; energy, transport, industry, agriculture, forestry and waste management; and economic diversification. Among these four windows, adaptation has the top priority.

Eligibility and funding The eligibility criteria and policies for projects and programs financed under the SCCF require that all projects and programs should be consistent with the mandate, goal and objectives of

criteria the SCCF and be consistent with relevant national reports, strategies, policies, plans and legislation. The LDCF/SCCF Council document: Operationalizing Support to the Preparation of the

National Adaptation Plan Process in Response to Guidance from the UNFCCC COP (GEF/LDCF.SCCF.14/06) guides the programming and defines the objectives, principles, scope and modali-

ties for GEF support, through the SCCF.

Application require- There is no explicit requirement for applicants to provide information on M\&A synergies.

ments

Monitoring and reporting Applicants monitor and report on progress towards adaptation outcomes and impacts. As with the LDCF, there is thus no explicit reporting requirement on M\&A synergies.

M \& A synergies are/may As per GEF-6 programming direction.

be promoted through. 


\section{Table 4: GEF climate change projects (full-size, medium-size, enabling projects), objective and funding criteria}

\section{GEF climate change projects}

Objective

Eligibility and funding

criteria

Application requirements

Monitoring and reporting requirements

$M \&$ A synergies are/may be promoted through..

GEF climate change projects seek solution for integrated approaches that account for the needs and interconnections between the many environmental dimensions at the local, regional and global levels. Mitigation actions involve direct reduction of GHG emissions through, for example, the scaling up of integrated urban management, sustainable transport, renewable energy and energy efficiency. But effective mitigation also includes reducing emissions from other sectors, such as land use and forestry, and protecting carbon sinks such as the oceans. GEF has also

Country eligibility: Countries eligible for funding if they have ratified the conventions the GEF serves or if it is an eligible recipient of UNDP technical assistance through its target for resource assignments from the core (specifically TRAC-1 and/or TRAC-2). National priority: Project must be driven by national sustainable development priorities. GEF priorities: Project address one or more of the GEF focal area strategies (Biodiversity, International Waters, Land Degradation, Chemicals and Waste, and Climate Change Mitigation, as well as crosscutting issues like sustainable forest management). Financing: Funding limited to the agreed incremental costs on measures to achieve global environmental benefits. Participation: Must involve the public in project design and implementation.

Medium and full sized projects should state by focal area the project contribution to global environmental benefits, M/A benefits as well as socio-economic benefits and consistency with national priorities. There is no explicit requirement of stating potential M\&A synergies.

An M\&E plan will be developed based on the proposed Project Results Framework. Thus no explicit requirement to report on M\&A synergies.

The GEF will continue to harness synergies between trust funds, GEF focal areas and multi-lateral environmental agreements.

GEF's Cross-Cutting Capacity Development Strategy (2014-2018) aims at catalyzing synergies and emphasizes integration of environmental sustainability across key development sectors.

GEF-6 programming direction has also selected 3 priority themes/pilot program where GEF may assist in transforming and scaling up the ongoing work of others. The themes are (a) Taking Deforestation out of Commodity Supply Chains; (b) Sustainable Cities - Harnessing Local Action for Global Commons; and (c) Fostering Sustainability and Resilience for Food Security in Sub-Saharan Africa.

At COP 21, the GEF was further requested to consider, starting in 2016, how to support developing countries in formulating policies, strategies and projects to implement activities that advance priorities identified in their intended nationally determined contributions ((I)NDCs). As part of its response, the GEF is encouraging governments to align the GEF programming for GEF-6 with INDC priorities and cite the relationship with relevant (I)NDCs in their funding proposal submissions. The Work Program for the June $2016 \mathrm{GEF}$ Council includes projects that support mitigation actions identified in the (I)NDCs, as summarized in the Work Program cover note. 
The CTF empowers transformation in middle income and developing countries by providing resources to scale up the demonstration, deployment, and transfer of low carbon technologies with a significant potential for long-term greenhouse gas emissions savings. The majority of CTF funding is addressing clean technologies such as renewable energy, energy efficiency, and clean transport.

The SCF provides support for three targeted programs with dedicated funding to pilot new approaches with potential for scaled-up, transformational action aimed at a specific climate change challenge or sectoral response: Forest Investment Program (FIP); Pilot Program Climate Resilience (PPCR); Scaling Up Renewable Energy Program (SREP):

The FIP aims to support developing countries' efforts to reduce emissions from deforestation and forest degradation by providing scaled-up financing for readiness reforms and public and private investments.

The PPCR supports pilot and demonstrate ways to integrate climate risk and resilience into core development planning, while complementing other ongoing activities. The SREP aims at demonstrating the social, economic, and environmental viability of low carbon development pathways in the energy sector.

Eligibility and funding Applicants to CTF are required to provide information on the project's consistency with CTF investment criteria, mainly on potential GHG reductions and cost effectiveness. The developcriteria ment impact descriptions could in principle address (synergies with) adaptation, but this cannot be observed in the project descriptions. Safeguards Policy Filter reports and Safeguard Screening forms do not address adaptation or climate resilience aspects.

Depending on the specific focus areas of the project, applicants to SCF and its three targeted programs (FIP, PPCR and SREP) may address both mitigation and adaptation aspects in focus areas and in environmental and social safeguard assessment of the Project Document, but this is far from done in all projects.

Application and reporting requirements

FIP pilot countries are to report on common themes in terms of i) GHG emission reductions / enhancement of carbon stocks; and ii). livelihoods co-benefits; as well as other relevant cobenefit themes as they apply to the country investment plan (e.g. environmental co-benefits, governance, capacity development, etc). The methodology for this is self-reported by the country. ${ }^{25}$

PPCR pilot countries are to report on five core indicators, two at national level and 3 at project/programme level. They are:

1) Degree of integration of climate change in national, including sector, planning

2) Evidence of strengthened government capacity and coordination mechanism to mainstream climate resilience

3) Quality and extent to which climate responsive instruments/investment models are developed and tested

4) Extent to which vulnerable households, communities, businesses, and public sector services use improved PPCR supported tools, instruments, strategies, and activities to respond to climate variability or climate change

5) Number of people supported by the PPCR to cope with the effects of climate change.

SREP: Each program/project is to report on two core indicators: a) Annual electricity output from renewable energy, as a result of SREP interventions, and b) Number of women and men, businesses and community services benefitting from improved access to electricity and fuels, as a result of SREP interventions Also, to report on a number of development co-benefits

indicators such as increased public and private investments in targeted subsectors as a result of SREP interventions, gender impacts, GHG emissions avoided or other co-benefits identified.

M \& A synergies

CIF works to disseminate knowledge being built within the thematic area of climate change, across the programmes. PPCR has inter alia collected a "top 10 Key Lessons" from the PPCR are/may be pro

through... highlighting critical and strategic aspects that need to be considered in resilience planning and implementation in sectors such as agriculture and landscapes, water resources, coastal zone, urban development, climate information systems, and other infrastructure sectors. ${ }^{26}$ The PPCR Sub-Committee requests the MDBs and new pilot countries to design the SPCRs to attract
funding from other sources, including the GCF, in addition to any resources that may become available in the PPCR. The Sub-Committee also encourages further collaboration between PPCR pilot countries, MDBs, the GCF and the CIF Administrative Unit on the development of SPCRs to facilitate compatibility with GCF's future investment criteria.

$25 \mathrm{https}: / /$ www-cif.climateinvestmentfunds.org/sites/default/files/knowledge-documents/fip_monitoring_and_reporting_toolkit_final_march_2016.pdf

${ }^{26}$ Key lessons from the PPCR, A practical resource for all involved with strategic planning processes and mainstreaming of climate resilience, World Bank Group PPCR Team, 2015. 


\section{Table 6: Nordic Development Fund (NDF) objective and funding criteria}

\section{Nordic Development Fund (NDF)}

Objective

NDF's objective is to provide financing and knowledge for climate change adaptation and mitigation and development activities primarily in low-income countries (LIC) in Africa, Asia and Latin America, in line with the Nordic countries' priorities in the area. Grants are the main instrument of NDF. ${ }^{27}$

Eligibility and funding The NDF strategy from $2015 \mathrm{sets}^{28}$ in addition to core project criteria of climate relevance and economic viability, a number of strategic criteria have been formulated based on NDF's strategic focal areas to ensure optimal value added by referring to that synergies may be most apparent in renewable energy-forestry-land management linkages.

The NDF applies a specific screening methodology to assess the climate change content of projects ex-ante. Core project criteria on adaptation projects require inter alia that projects should be primarily climate-related, i.e. at least $50 \%$ of total project investment costs would be incurred due to measures helping to adapt and build resilience to the current or expected impacts of climate change. The parallel criteria for mitigation projects are that projects should have a significant climate component, i.e. the global benefits of GHG emission reduction or carbon sequestration should be at least $10 \%$ of project investment costs.

Application and report- Funding level per project ranges from EUR 3 million to EUR 6 million. Specific reporting requirements related to climate change do not seem publicly available and it is thus assumed that ing requirements reporting on the projects is mainly based on the specific application, related grant agreement and implementation agreement.

M \& A synergies

re/may be promoted

through...

In addition to the core project criteria on climate relevance and economic justification, the strategic criteria may be applied for promoting better synergies between mitigation and adaptation, e.g. support for innovation in order to identify interventions with potential to drive transformative change for climate resilient growth and identification or emerging climate change issues, and interlinkages with other emerging issues, such as the nexus between climate change, ecosystems, biodiversity and natural capital. Other project level aspects refer amongst others to the alignment with the SDGs and Nordic development policy priorities.

${ }_{27}$ More info on the NDF climate change portfolio data can be found at: http://www.ndf.fi/sites/ndf.fi/files/attach/ndf_climate_change_portfolio_as_of_22_june_2016_o.pdf

${ }^{28}$ Agile and Innovative NDF looking ahead, NDF strategy, November 2015.

29 Guidelines for Project Identification and Screening, NDF, February 2016 


\section{Table 7: Nordic Climate Facility (NCF) objective and funding criteria}

\section{Nordic Climate Facility (NCF)}

Objective

The Nordic Climate Facility (NCF) is financed by the Nordic Development Fund and administered by the Nordic Environment Finance Cooperation (NEFCO). The NCF has since its launch in 2009 financed projects balanced within three categories: Adaptation, mitigation and a combination of the two. The NCF launches calls for innovative project concepts each with a specific theme, and has to date carried out six calls for proposals.

The main objectives of the NCF are to (i) facilitate the exchange of technology, knowledge, know-how and innovative ideas between the Nordic countries and low-income countries in the field of climate change, (ii) to increase the low-income countries' capacity to mitigate and adapt to climate change; and (iii) to contribute to sustainable development and the reduction of poverty. Furthermore, the NCF's objective is also to encourage testing of concrete concepts relating to climate change and to facilitate partnerships.

Eligibility and funding criteria

The NCF finances projects that are both climate and development projects. The projects should have a potential to promote technological innovation in areas susceptible to climate change such as: energy, transport, water and sanitation, health, agriculture, and forestry and other areas related to natural resource management, and through calls for proposals focusing on adaptation to and/or mitigation of climate change.

Application and report- One project can receive a grant between EUR 250,000 and 500,000 and the maximum support time period is 2.5 years. As the purpose is to support small-scale projects, longer term monitorin ing requirements (beyond project finalisation) is currently not required or possible for the NCF, thus the impacts and outcomes are collected through the final reporting on the projects.

M \& A synergies are/may NCF has further analysed its portfolio and concluded inter alia that the traditional distinction between mitigation and adaptation fails to depict the variety of linkages between mitigation be promoted through ... and adaptation and may lead to underutilized opportunities for synergies, ${ }^{30}$ and that also private sector funding needs to be more facilitated in this direction of promoting synergies.
.

\section{Table 8: Nordic bilaterals (Finland, Norway, Sweden, Denmark), objective and funding criteria}

Nordic bilaterals (Finland, Norway, Sweden, Denmark)

Objective

All Nordic countries focus on mitigation and adaptation, however to a varying degree on mitigation and adaptation respectively, as well as on potential synergies and co-benefits. E.g. the Danish NEC-strategy (Natural Resources, Energy and Climate Change Strategy, 2013) mentions explicit both mitigation and adaptation as focus areas, but does not further elaborate on the potential for synergies. Norway is focusing on climate change and access to clean energy, e.g. through Norway's International Climate and Forestry Initiative (NICFI). The NICFI focuses on thematic areas such as Securing Indigenous and Other Forest-dependent Populations' Rights and Interests, Deforestation-free Commodity Supply Chains and Green Growth, Improved Transparency, Governance and Legality, and Promoting International Consensus on REDD+.

Eligibility and funding Promotion of synergies and co-benefits are not seen to be very explicitly addressed at strategy or programme level in any of the bilateral funds, albeit implicitly in terms of more general criteria references to sustainable development, SDGs etc.

Application and reporting Specific reporting requirements related to synergies and co-benefits do not seem integrated in the bilateral funds but may be treated as part of specific applications, project and grant requirements agreements.

M \& A synergies are/may More explicit guidance on potential synergies both in programming purposes and for guidance at concrete project level. Explicit indicators and reporting requirements may likewise be be promoted through... integrated as part of the programming and project cycles.

${ }^{30}$ Mobilizing private sector funds for climate change adaptation: Nordic Climate Change Facility (NCF) as a case study, K. Haemekoski, H. Sinko. 
Nordic Council of Ministers

Ved Stranden 18

DK-1061 Copenhagen K

www.norden.org

Mitigation \& Adaptation Synergies in the NDCs

Signatories of Paris Agreement outlined their post-2020 climate actions, known as their Intended Nationally Determined Contributions (I)NDCs.

This study focuses on potential synergies between adaptation and mitigation in the (I)NDCs. It pays particular attention to the sectors of forestry, agriculture, energy and urban development. It draws on a review of climate change financing literature, and an analysis of the (I)NDCs and the financial and policy frameworks and programmes that make up global climate change financing structure, notably the texts of the Paris Agreement. The report contains recommendations for Nordic stakeholders to drive further synergies between mitigation and adaptation.

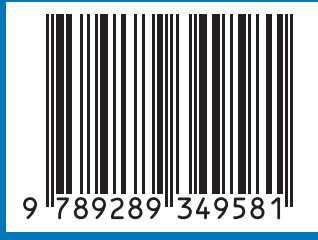

